\title{
THE PHYSICAL AND CHEMICAL OCEANO- GRAPHY OF THE WATERS BATHING THE CONTINENTAL SLOPE OF THE CELTIC SEA
}

\author{
By L. H. N. Cooper, D.Sc. F.R.I.C.
}

Chemist at the Plymouth Laboratory

(Text-figs. I-I5)

\section{CONTENTS}

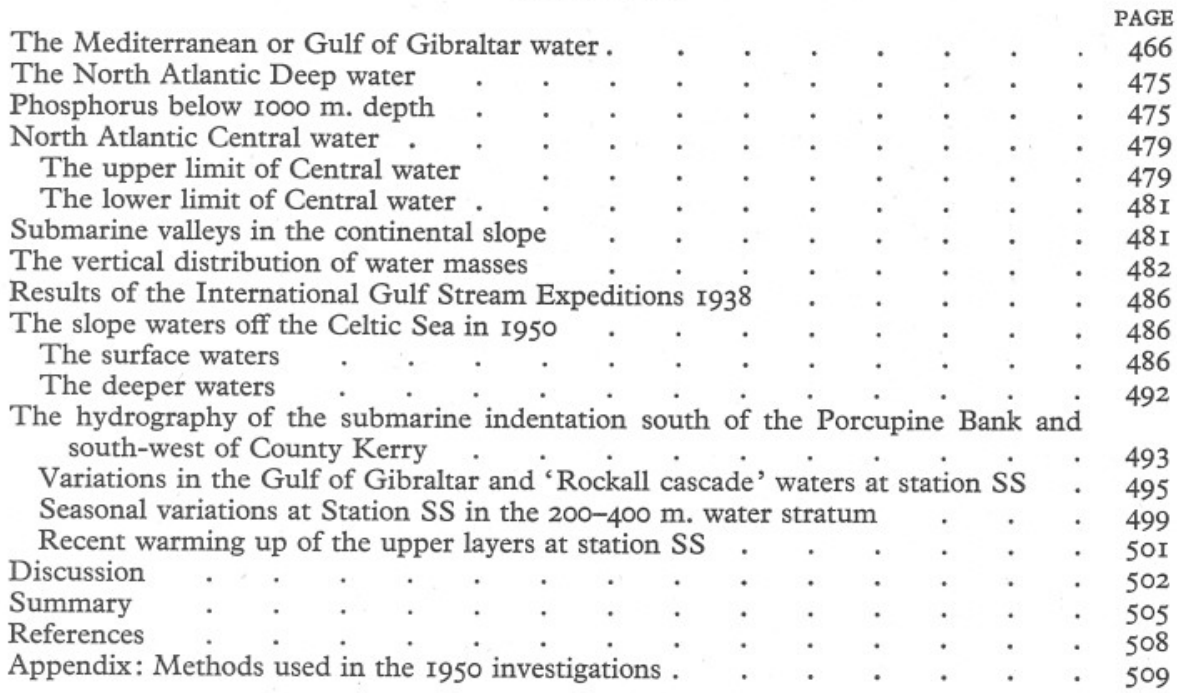

Knowledge of the hydrography of the English Channel and Celtic Sea is needed as a background for the life histories of the mackerel, pilchard and herring and, indeed, of every organism living within range of the Plymouth Laboratory. Such knowledge can never be fully attained until we know more of the exchanges with the deep Atlantic Ocean which take place 200-300 miles to the south-west and west over the continental slope. Moreover, at the slope we shall need to know not only what waters move in and out but what move up and down. Long ago Storrow (1925), and no doubt others, saw clearly some of the problems here to be discussed, but they were unable to bring factual evidence to bear. A critical reconstruction of the considerable but fragmentary observations in the neighbourhood of the continental slope of the Celtic Sea will be presented here and supplemented by observations made in I950 with the generous co-operation of the vessels of the National Institute 
of Oceanography (Discovery Committee) and in 1948 by H.M. Surveying Ship Dalrymple. Though many of the conclusions remain tentative, it should now be easier to design observational work at sea to test specific hypotheses at the right time and place by the methods of experimental oceanography. The numerical results in 1950 will be published by the Conseil International pour l'Exploration de la Mer.

In addition to acknowledgements in the text and to many colleagues at the Plymouth Laboratory, thanks are due to the Hydrographer of the Navy for his cordial assistance in many ways and to Dr J. N. Carruthers of the Hydrographic Office, who has frequently constructively assisted from his unrivalled knowledge of the literature. He and $\mathrm{Mr} \mathrm{G}$. A. Steven of this laboratory have provided anvils upon which some of the ideas and nomenclature have been hammered out. Mr F. A. J. Armstrong, not only by carrying out all the laboratory analyses and by his critical faculty but by relieving me of many day to day duties, has much furthered this work. Insufficient acknowledgement has been made in the text of the great debt due to the writings of the Scandinavian school of oceanographers, in particular those of B. HellandHansen, F. Nansen, J. W. Sandström and H. U. Sverdrup and to those of the Canadian investigator, A. G. Huntsman, and the American, C. G. Rossby.

\section{The Mediterranean or Gulf of Gibraltar Water}

The highly saline deeper water (salinity $>38 \%$ ) from the Mediterranean Sea spills over the sill of the Straits of Gibraltar and flows downhill, mixing vigorously the while with Atlantic water mostly North Atlantic Central water (p. 479) with a salinity around $36 \%$. The mixed water attains a density around $\sigma_{t} 27 \cdot 6-27 \cdot 8$ and spreads out as an intrusive plate or tongue into the Atlantic at around $1000 \mathrm{~m}$. depth, slowly mixing further with the waters above and below (Helland-Hansen \& Nansen, 1927). This 'Mediterranean' water has never been shown to be of importance for studies of surface hydrography in our area, but there is little doubt that it is.

When only salinity, temperature and oxygen have been considered the name 'Mediterranean' has been clear and unambiguous but, when applied in nutrient and productivity studies, it is misleading. 'Mediterranean' suggests a water very poor in nutrients. In fact the $1000 \mathrm{~m}$. stratum here is relatively rich, since it includes a large component of enriched Intermediate or Central water from the equatorial Atlantic at 700-I200 m. depth. When this water upwells here, the upper layers will not be seriously impoverished, as the name 'Mediterranean' would suggest, but enriched. A truly descriptive name should suggest that we have to do with a new water mass created in the Atlantic Ocean west of the Straits of Gibraltar which Vallaux (1936) has neatly described as the 'Gulf of Gibraltar'. In this paper, henceforth, the 
term 'Mediterranean water' will be replaced by 'Gulf of Gibraltar water'. I am indebted to Dr J. N. Carruthers for suggesting this.

From the way in which this water has been formed one would expect it to be markedly heterogeneous (Nielsen, I9I2, pp. I79-82), and in our area it is. It cannot be identified by any point on a temperature-salinity diagram but only by an area. The point $G\left(9 \cdot 00^{\circ} \mathrm{C}\right.$., $\left.35.70 \% S\right)$ which we shall use to represent it on $T-S$ diagrams is a useful statistical fiction which expresses the fact that, during the slow mixing of Gulf of Gibraltar water with North Atlantic deep water (and no doubt with North Atlantic Central and cascade waters), short-period and considerable fluctuations in the properties of the former become ironed out so that the mixed water approximates closely to the linear temperature-salinity relation:

$$
S=35 \cdot 25_{8}+0 \cdot 14_{7}(T-6) .
$$

Before the results of the 1938 International Gulf Stream Expeditions had reached this country (see p. 486) this expression had been derived by the method of least squares from Armauer Hansen stations 7-I 5 of I9I4 (HellandHansen \& Nansen, 1927), and other scattered observations where oxygen observations were available.

Although the temperature and salinity of the Gulf of Gibraltar water vary much, the percentage saturation with oxygen does not. Between Armauer Hansen stations 7 and I5 (Gaarder, I927) the temperature of this water ranged from 8.37 to $10.44^{\circ}$ C. and the salinity from 35.52 to $35.75 \%$, whereas the oxygen content lay always between 65 and $68 .{ }_{5} \%$ saturated. This property will sharply distinguish Gulf of Gibraltar water from cascaded or 'capsized' water (Cooper, I952a) of similar temperature and salinity, but not from North Atlantic Central water which at similar depths has similar oxygen percentage saturation.

The impoverished deeper water of the Mediterranean is even more deficient in phosphate than it is in nitrate; it has a large positive anomaly of the nitratephosphate ratio. In the Gulf of Gibraltar this Mediterranean water mixes with North Atlantic Central having (for the North Atlantic) a high content of nutrients and a normal nitrate-N-phosphate-P ratio of about I5: I. Off the Iberian Peninsula, Thomsen's (I93I) results showed that the nitrate-phosphate ratio in the newly formed Gulf of Gibraltar water, after correction for phosphate salt error, may be as high as 40: I. By the time it has flowed to the border of the Celtic Sea, this water may be still poorer than North Atlantic Central water at the same depth but, from the point of view of upwelling, it must be regarded as a relatively rich water, in which the anomalous nitratephosphate ratio has almost disappeared (Cooper, 1937, I938a).

The very variable extension from time to time of Gulf of Gibraltar water was shown by five stations worked by the present H.M.S. Challenger at a single truly oceanic position $44^{\circ} 36^{\prime}$ N., $20^{\circ} \mathrm{o0^{ \prime }}$ W. (Cons. Int., Bull. Hydrogr. 
for the respective years), supplemented by the nearby Deutschland station (Reihe) 4 (Brennecke, I92I) (Table I).

For standard depths on the six occasions mean values of temperature and salinity have been calculated; the deviations from these means are presented in Fig. I, from which it will be seen that between 0 and $700 \mathrm{~m}$. depth the range of temperature and salinity was $\mathrm{I} \cdot 2^{\circ} \mathrm{C}$. and $0.20 \%$ respectively. The relatively much larger fluctuations at 750 and $1000 \mathrm{~m}$. depth are more clearly shown by the standard deviations at standard depths graphed in Fig 2 . Most striking of all was the very rapid increase in both temperature and salinity in the $4 \frac{1}{2}$ months between 29 November I932 and I4 April I933

\begin{tabular}{|c|c|c|c|c|c|}
\hline Ship & $\begin{array}{c}\text { Station } \\
\text { no. }\end{array}$ & Date & Lat. & Long. & $\begin{array}{l}\text { Depth } \\
\text { (m.) }\end{array}$ \\
\hline Deutschland & & 20. v. II & $45^{\circ} \mathrm{I} 3^{\prime} \mathrm{N}$. & $20^{\circ} 07^{\prime} \mathrm{W}$. & - \\
\hline Challenger & 1292 & 29. ix. 32 & $44^{\circ} 37^{\prime} \mathrm{N}$. & $20^{\circ} 00^{\prime} \mathrm{W}$. & 4372 \\
\hline Challenger & I318 & I4. iv. 33 & $44^{\circ} 35^{\prime} \mathrm{N}$. & $19^{\circ} 56^{\prime} \mathrm{W}$ & 4170 \\
\hline Challenger & 1556 & I8. iv. 34 & $44^{\circ} 35^{\prime} \mathrm{N}$ & $20^{\circ} 00^{\prime} \mathrm{W}$. & 4315 \\
\hline Challenger & 1666 & I4. iv. 35 & $44^{\circ} 40^{\prime} \mathrm{N}$. & $20^{\circ} 00^{\prime} \mathrm{W}$. & 4546 \\
\hline Challenger & I 772 & I3. iv. 36 & $44^{\circ} 36^{\prime} \mathrm{N}$. & $20^{\circ} 00^{\prime} \mathrm{W}$. & 4546 \\
\hline
\end{tabular}

TABLE II

\begin{tabular}{|c|c|c|c|c|c|c|}
\hline \multirow{2}{*}{$\begin{array}{l}\text { Depth } \\
\text { (m.) }\end{array}$} & \multicolumn{3}{|c|}{ Temperature $\left({ }^{\circ} \mathrm{C}.\right)$} & \multicolumn{3}{|c|}{ Salinity $(\%)$} \\
\hline & 29. ix. 32 & I4. iv. 33 & $\Delta T$ & 29. ix. 32 & I4. iv. 33 & $\Delta S$ \\
\hline $\begin{array}{r}750 \\
1000\end{array}$ & $\begin{array}{l}8 \cdot 84 \\
7 \cdot 26\end{array}$ & $\begin{array}{r}9 \cdot 76 \\
7.86\end{array}$ & $\begin{array}{l}0.92 \\
0.60\end{array}$ & $35 \cdot 37$ & $35 \cdot 56$ & 0.19 \\
\hline
\end{tabular}

(Fig. 3 and Table II). Thus at the level of the Gulf of Gibraltar water there were large variations from year to year in the middle of April and very rapid changes in the course of a few months. This conclusion is confirmed by the findings at the Irish station SS on the continental slope (Table XV and Fig. 2), and would probably have been found anywhere in the eastern North Atlantic.

The capacity of these deep-water movements to transport heat about the world is great. Thus this short-period increase in heat content at $44^{\circ} 36^{\prime} \mathrm{N}$., $20^{\circ} \mathrm{o0^{ \prime }} \mathrm{W}$. of a column of water I cm. ${ }^{2}$ cross-section would have been sufficient to raise the temperature of all the air above a surface of $308 \mathrm{~cm}^{2}$ by $\mathrm{I}^{\circ} \mathrm{C}$. Otherwise stated, the increase in temperature of the water below roo square sea miles would have been sufficient to raise the temperature of all the air over Great Britain by $0.5^{\circ} \mathrm{C}$. The Gulf of Gibraltar water should not be regarded as permanently sealed down and of no account in surface oceanography and meteorology.

Vallaux (1936) has already directed attention to the highly heterogeneous nature of the Gulf of Gibraltar water. He pictures it as fragmented into a series of globular masses dispersing both in depth and expanse through the North Atlantic and gradually merging with it.

In 1906 the Thor (Schmidt, I9I2), in the course of her investigations on the breeding place of the eel, worked a number of hydrographical stations along 


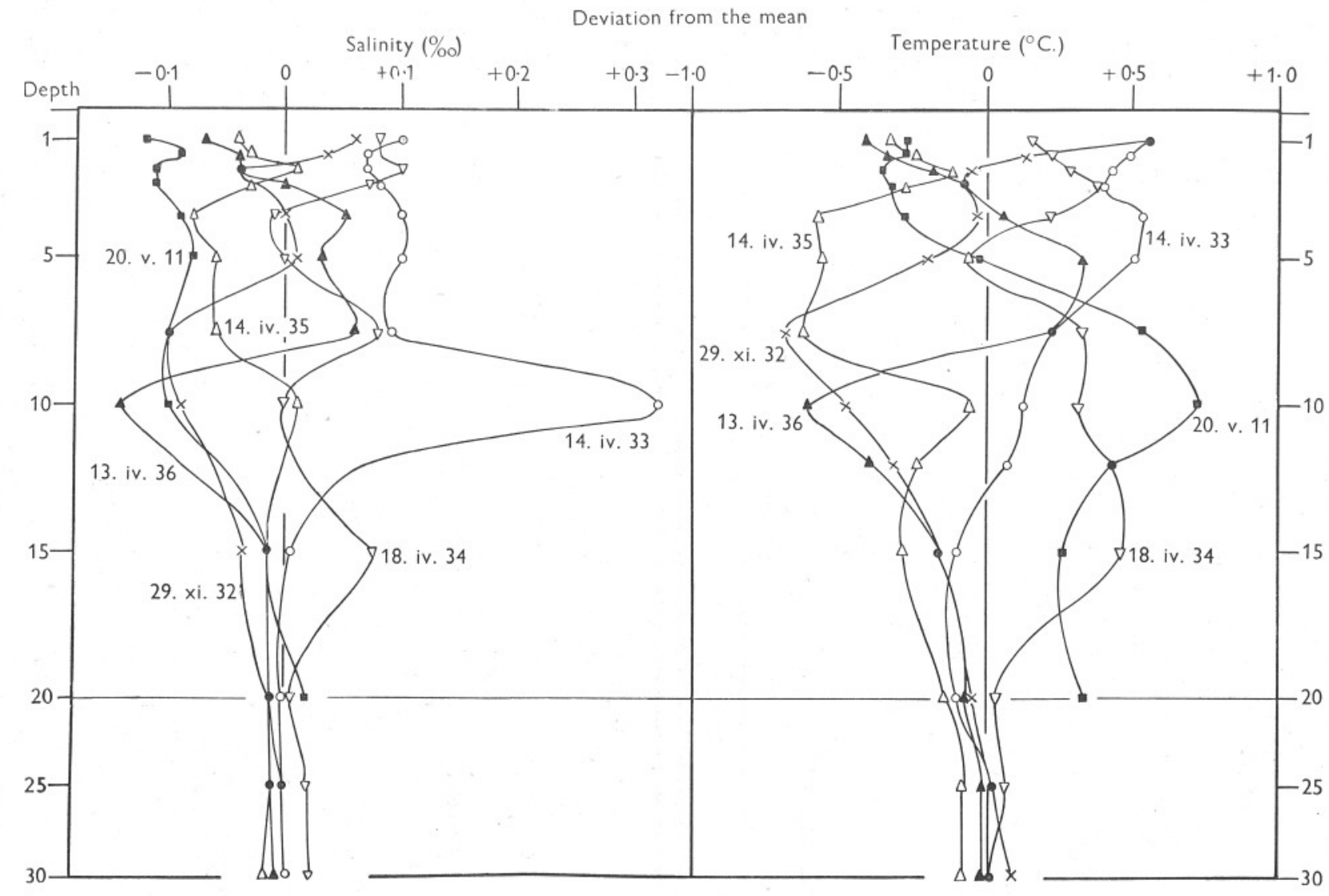

Fig. I. Salinities (left) and temperatures (right) from standard depths at six stations in the North Atlantic near $44^{\circ} 36^{\prime} \mathrm{N} ., 20^{\circ} 00^{\prime}$ W. (Table I), expressed as deviations from the respective mean values at each depth. Black circles indicate coincident points on two or more curves. Depths in hundreds of metres. 


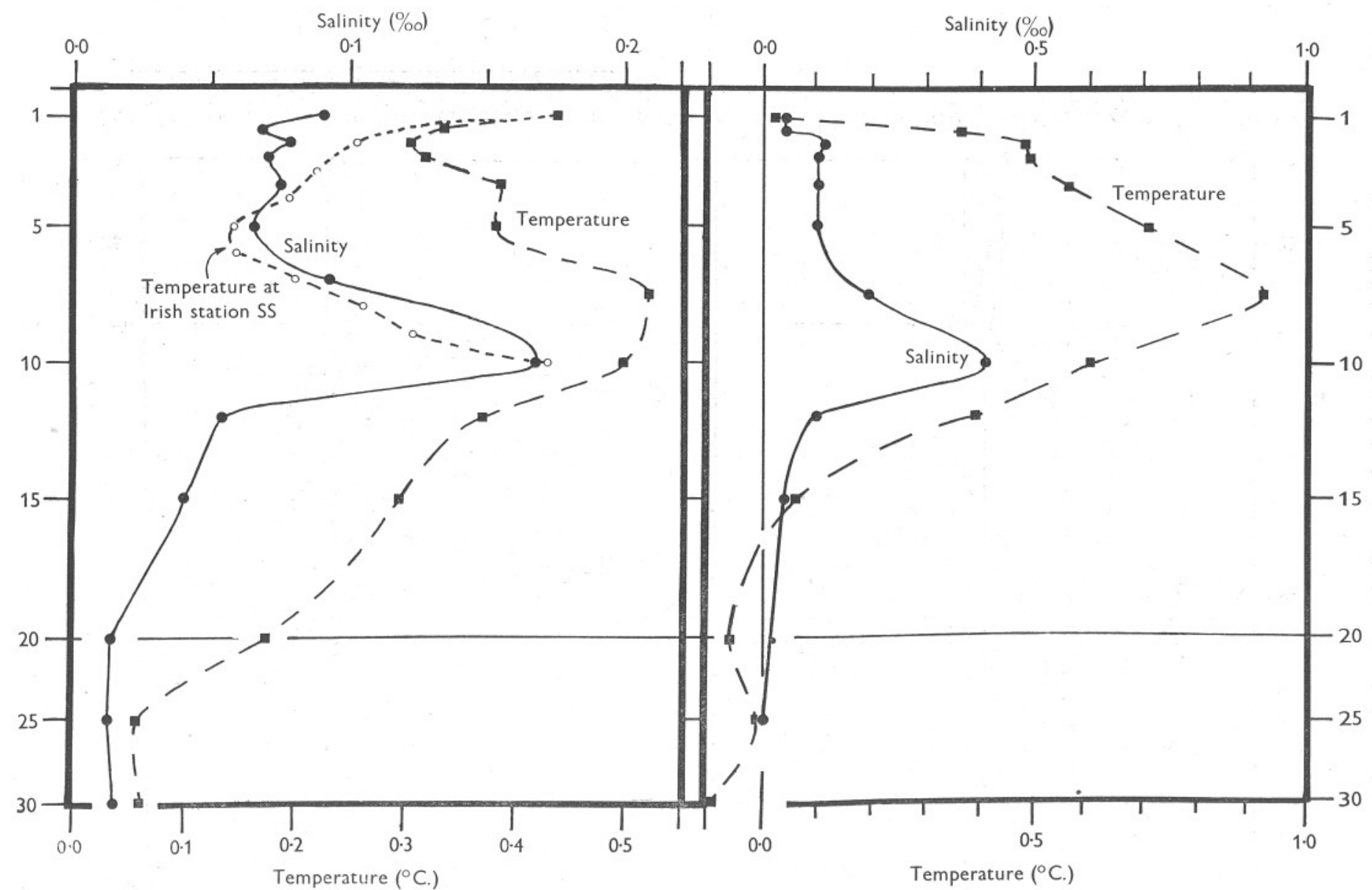

Fig. 2. Standard deviations of temperature and salinity based on six sets of observations at or near $44^{\circ} 36^{\prime} \mathrm{N} ., 20^{\circ} \mathrm{00^{ \prime }} \mathrm{W}$.; also (open circles) standard deviations of temperature from twenty-nine sets of observations at the Irish station SS $\left(50^{\circ} 34^{\prime} \mathrm{N}\right.$., $\mathrm{II}^{\circ} 17^{\prime} \mathrm{W}$.) from Table XV.

Fig. 3. Increase in temperature and salinity between 29 November I932 and I4 April 1933 at $44^{\circ} 36^{\prime}$ N., I9 ${ }^{\circ} 58^{\prime}$ W. Depths in hundreds of metres. 
the slope of the Celtic Sea and Bay of Biscay. On Fig. 4 some stations worked between Io May and I7 June are denoted by circles and some between 26 August and 3 September by crosses. Section I (Fig. 5) ran in deep water along the edge of the slope. It is clear that the wedge of highly saline Gulf of Gibraltar water was held into the right on the Franco-Iberian coast, and

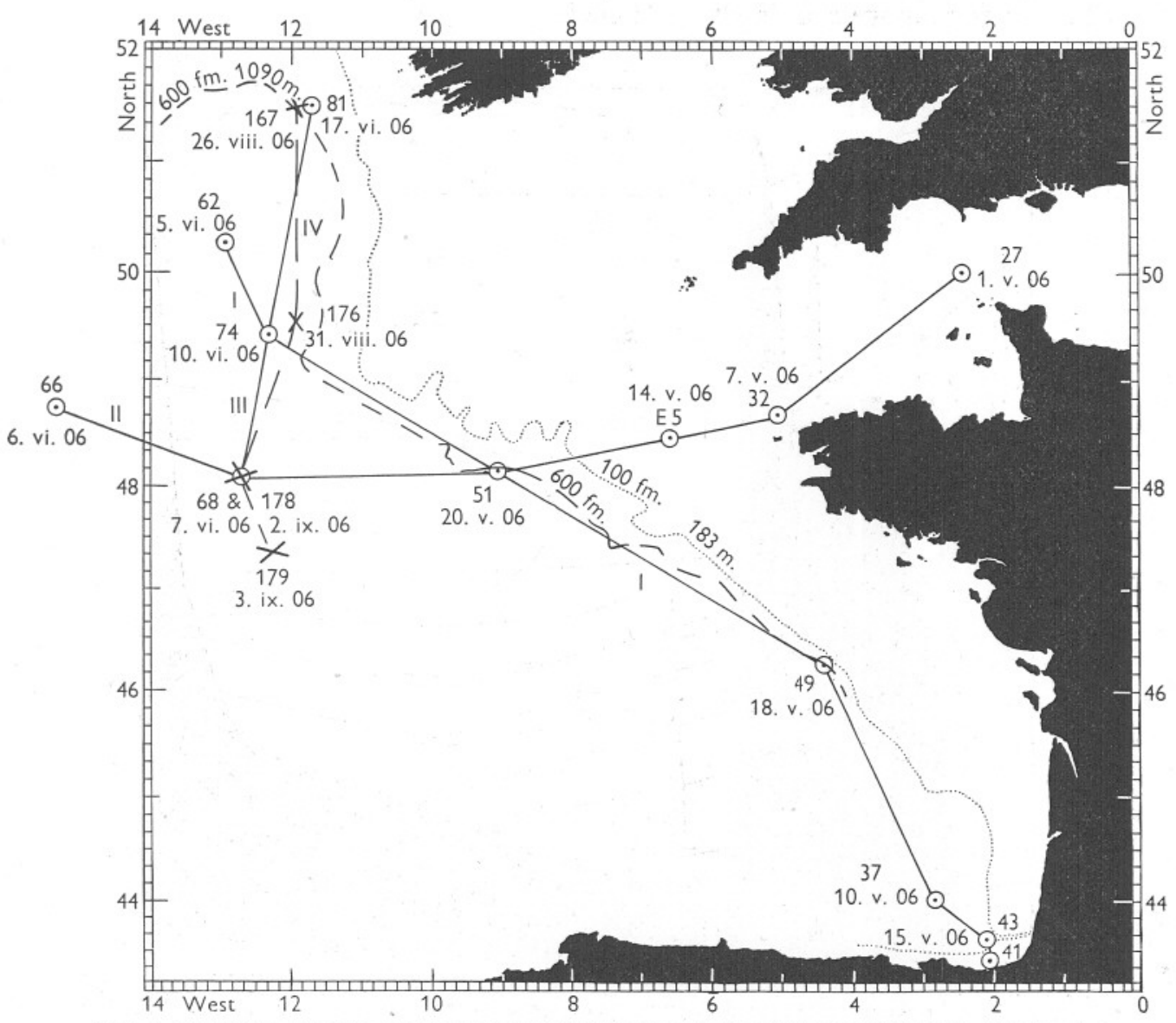

Fig. 4. Positions of some stations worked by the Danish research vessel Thor in 1906 and the International Hydrographic Station E5.

on 20 May was strongly represented as far north as station $5 \mathrm{I}\left(48^{\circ} \mathrm{0} 7^{\prime} \mathrm{N}\right.$., $9^{\circ} \mathrm{O}^{\prime}$ W.), south of the Celtic Sea. Between stations $5 \mathrm{I}$ and 74 , worked 3 weeks later, a slight bulge in the continental shelf has to be shown in section I. The submarine promontory west of the Little Sole and Great Sole Banks, shown by the 100 and $600 \mathrm{fm}$. contours on Fig. 4, seems to play a large part in the hydrography of the area and needs constantly to be in mind. In its neighbourhood there seems to have been a marked attenuation in the 
strength of the Gibraltar water then at station 74 and on other occasions. The continental slope changes in direction from west-north-west to northnorth-east and becomes the eastern boundary of a submarine gulf, bight or indentation. ${ }^{1}$ If Gibraltar water is to enter this indentation, the water already there must escape either as an eddy in a horizontal plane or by upwelling to levels where movement is less restricted.

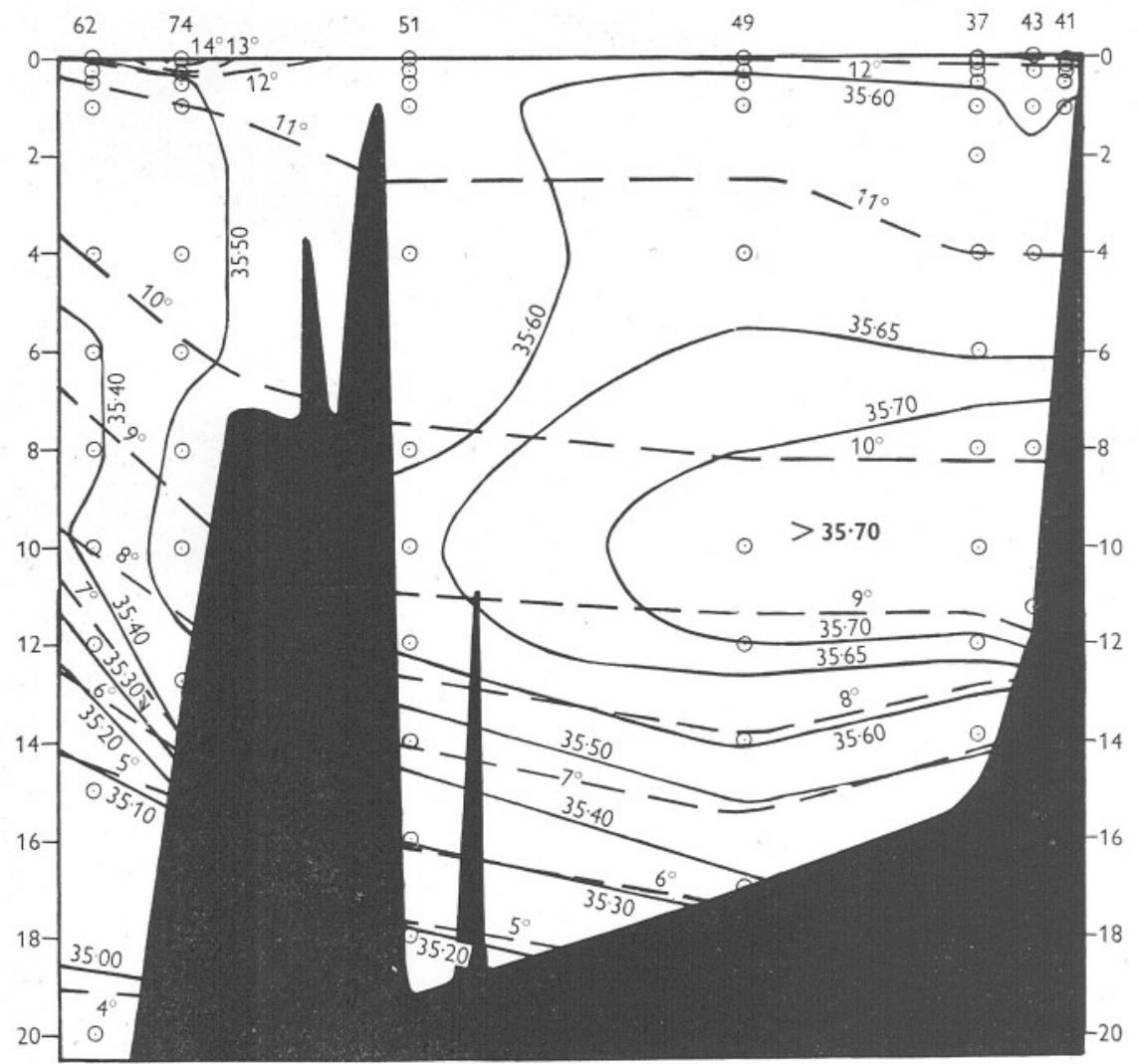

Fig. 5. Section I of Fig. 4 (stations 62-4I), based on temperatures and salinities observed by Thor between Io May and Io June I906. Bottom topography assessed from Admiralty charts. Depths in hundreds of metres.

Through or around this submarine promontory it is not easy to draw continuous curves for temperature and salinity between stations 5I, 74 and 62, spread over 200 miles. The waters north-west and south-east of the 'Sole' submarine promontory evidently have markedly different properties (Fig. 5).

1 The nomenclature of features such as this is at present under discussion. Possible confusion may be avoided by using the term 'indentation', unlikely to be acceptable to anyone as a permanent name for anything. Since it bites into the continental shelf of which the Porcupine Bank is a part it will here, for convenience of repeated reference, be called the 'South Porcupine submarine indentation'. 
Section II (Fig. 6) ran down the English Channel and over the continental slope south of the Little Sole Bank, crossing section I at station 5I. In the

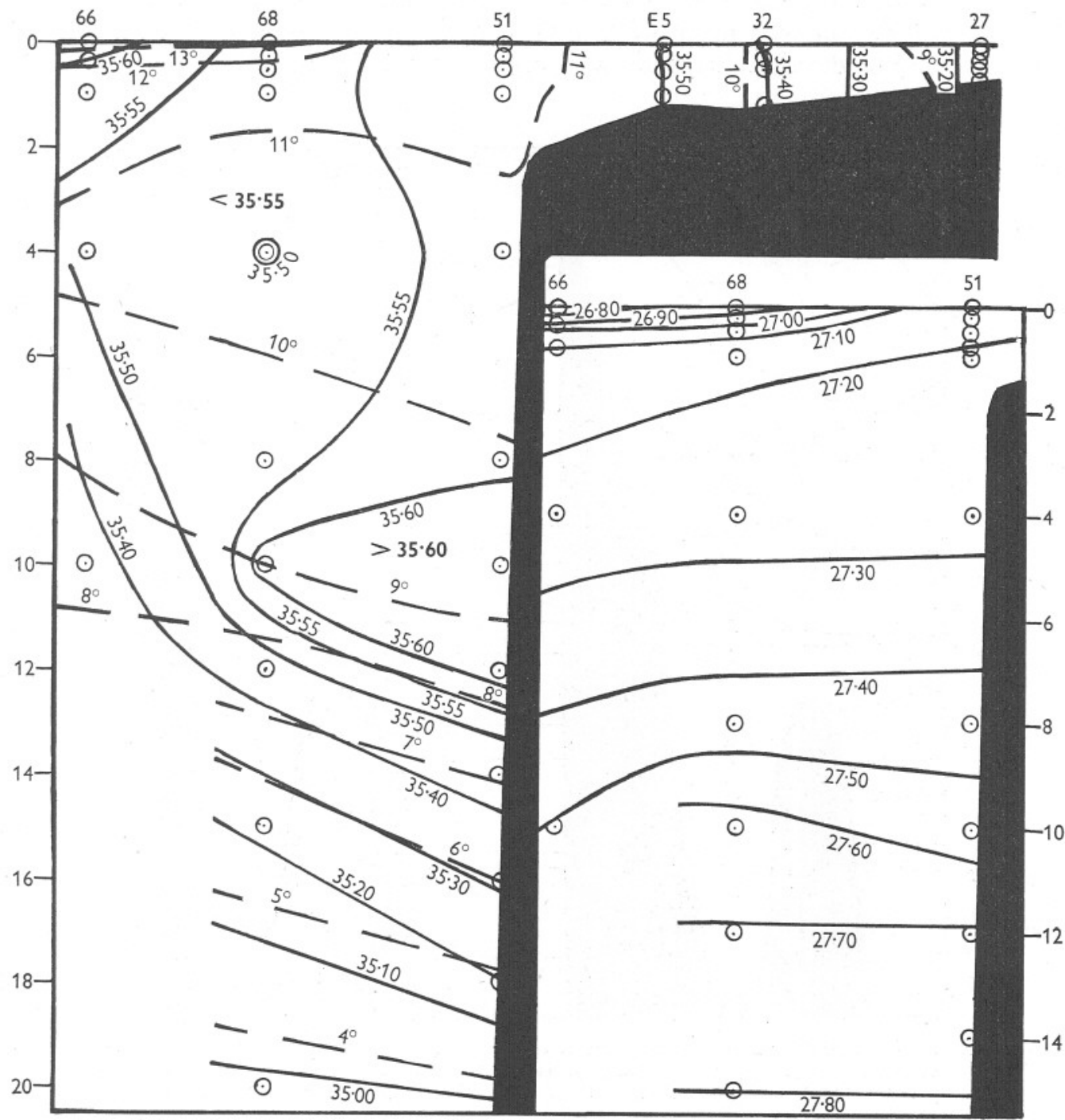

Fig. 6. Section II of Fig. 4 (stations 66-27), based on temperatures and salinities observed by Thor between I May and 7 June 1906. Inset bottom right, distribution of density $\left(\sigma_{t}\right)$. Depths in hundreds of metres.

uppermost $400 \mathrm{~m}$. the isopycnals incline downwards away from the continental slope (Fig. 6, inset) suggesting a weak surface current towards the south-east, confirmed from a study of the geopotential topography of the surface against 
the Ioo-decibar surface. Abreast of Ushant the Gulf of Gibraltar water at $1000 \mathrm{~m}$. was held in against the slope and did not extend very far westwards. The slope of the isopycnals for $\sigma_{t} 27.50$ and 27.60 suggests that this water mass was still moving west-north-west. Eighty miles off the slope at station 66 the influence of the Gibraltar water was very slight (salinity maximum $35 \cdot 34 \%$ ).

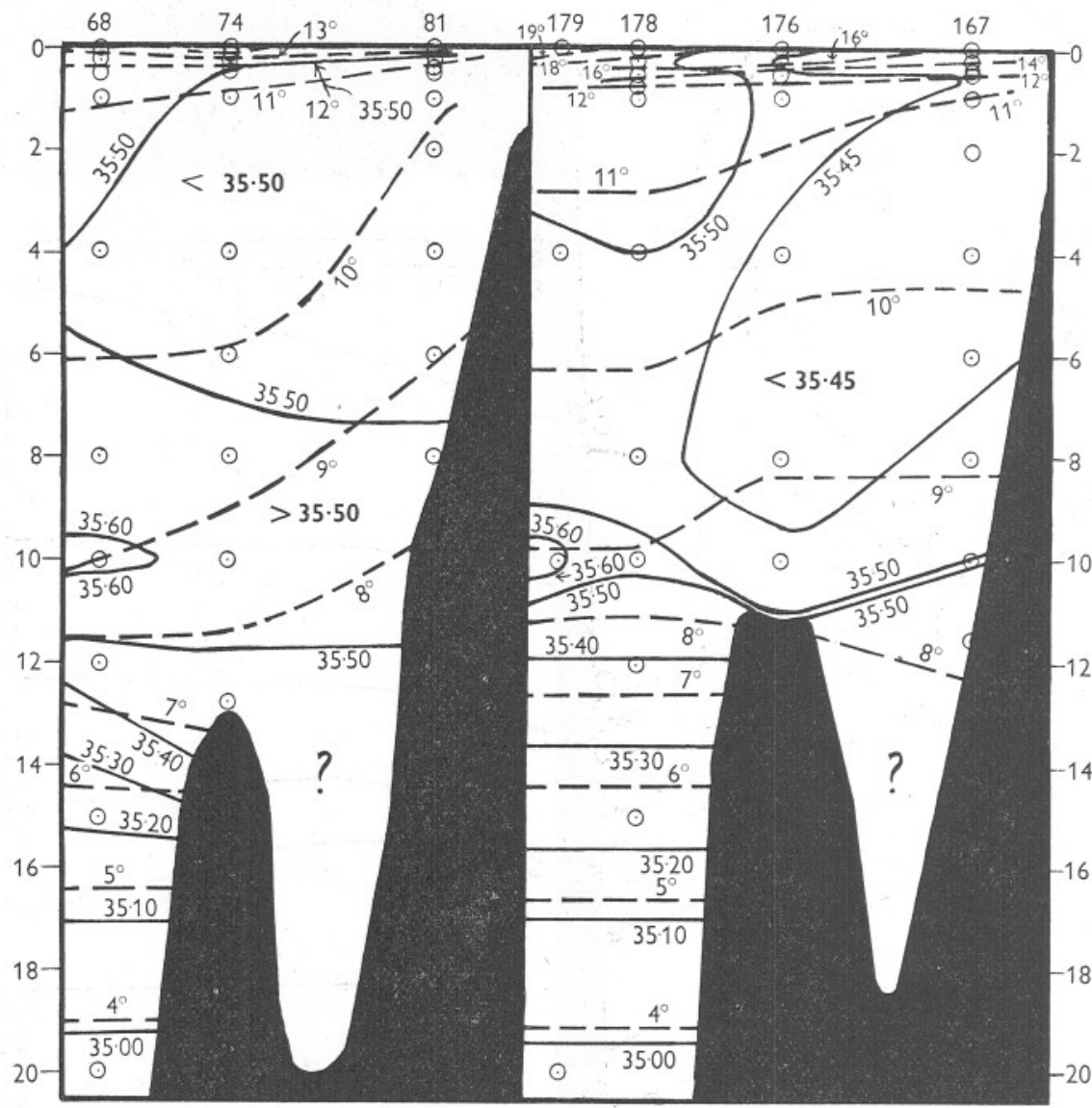

Fig. 7. North-south sections based on temperatures and salinities observed by Thor. Section III of Fig. 4 (stations 68, 74, 8I), 7-I7 June 1906; Section IV (stations I79, I78, 176, 167), 26 August-3 September, 1906. Depths in hundreds of metres.

On the north-south section III (Fig. 7, left), although the water at station 68 undoubtedly included a strong Gibraltar component, one cannot feel the same confidence about the water to the north within the submarine indentation with a salinity of $35 \cdot 52-35 \cdot 55 \%$, a temperature of $8.5-9.3^{\circ} \mathrm{C}$. and a density $\sigma_{t}$ of $27 \cdot 5 \mathrm{I}-27 \cdot 63$. These are compatible with a very considerable proportion of water cascaded from the Rockall Table Mount. 
Section IV (Fig. 7, right) shows the change, essentially along section III, in the next 3 months. There had been a marked withdrawal of the saline water at $800-1200 \mathrm{~m}$., causing a decrease in salinity of $0.06-0.10 \%$. The shape of the surfaces of equal density between stations 178 and 179 (not reproduced) also suggests a south-east-going current at these depths, where the water movements evidently are considerable.

\section{The North Atlantic Deep Water}

The deep water of the eastern North Atlantic can only remotely affect the surface water and is of importance to us only for the effect it may have on the stratum of Gulf of Gibraltar water around $1000 \mathrm{~m}$. depth, and as a component of a current system which impoverishes the nutrient regime of the whole of the North Atlantic compared with the other oceans (Sverdrup, Johnson \& Fleming, 1942, p. 754).

It is of interest, none the less, that the variations in temperature and salinity of the deep water near the continental slope at the positions italicized in Fig. 8 are quite considerable (Table III). This deep water has been formed, according to Nansen (I9I2), chiefly at the surface in a limited area south-west of Greenland and to some extent by the outflow from the Norwegian Sea through the bottom of the Faeroe-Shetland Channel (but see Cooper, I952 $b$ ). According to Helland-Hansen (I930, p. 75) a certain amount of Gulf of Gibraltar water appears to mix downwards to $5000 \mathrm{~m}$.

For the construction of temperature-salinity diagrams in this area the deep water may be characterized by the point $D$ having temperature $3.9^{\circ}$ and salinity $34.95 \%$. This point is not quite the same as Jacobsen's (I929) point $B$, derived from and employed for a much wider area.

The distribution of silicate in the deep water is discussed in a separate paper (Cooper, $1952 b$ ).

\section{PHOSPHORUS BELOW IOOO M. DEPTH}

There have been very few determinations of phosphate in the deep water near the continental slope of the Celtic Sea. On I7-I9 June I930 the Dana (Dana Report, No. I2, I937) worked for inorganic phosphate two stations 56 miles south and east respectively of Discovery II station 2659 of I2 May I950. The Dana results (Table IV) have been multiplied by $\mathrm{I} \cdot 35$ to correct for salt error (Cooper, I938b). They may be compared with the Discovery II results for total phosphorus which would be expected to be about $0^{\circ} \mathrm{I} \mu \mathrm{g}$.-atom $/ 1$. greater. Actually below $\mathrm{I} 200 \mathrm{~m}$. depth they were about $0.2 \mu \mathrm{g}$.-atom $/ 1$. less, a notable result if it is correct. The following comments may be made:

(i) Although, for reasons to be given (Appendix, p. 509), the accuracy of the analyses made on the Discovery II samples is not very high, there is little reason to doubt their accuracy to one decimal place as reported. 


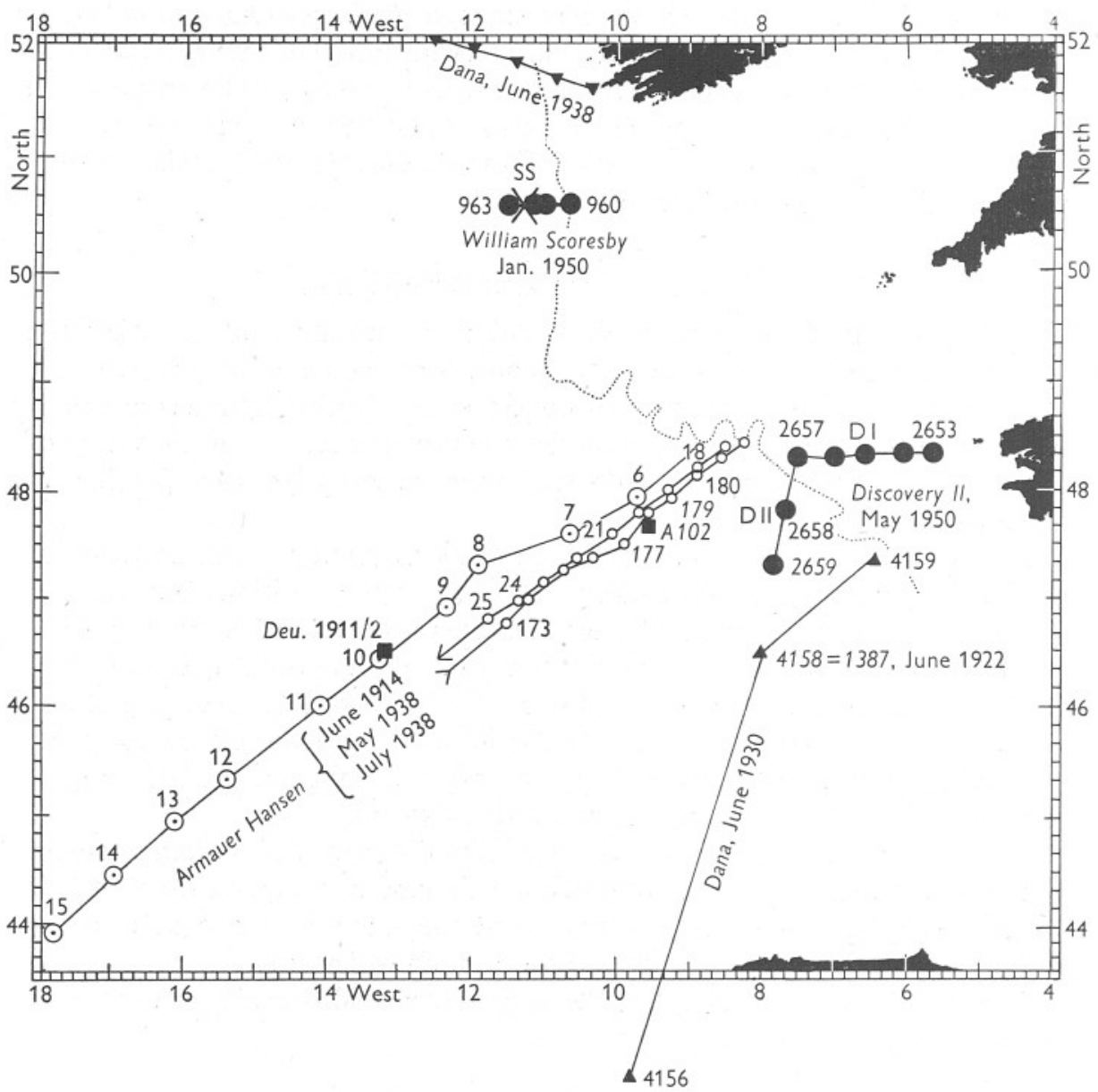

Fig. 8. Positions of deep stations off the continental slope of the Celtic Sea: $\odot$, Armauer Hansen stations in June I914; O, Armauer Hansen stations in May and July 1938; Dana stations in June 1930 and one in June I922; $\nabla$, Dana stations in June I938; - Deutschland Reihe 2 in May I9I I and Altair station IO2 in July I938; $\bullet$, stations by R.R.S. William Scoresby in January I950 and by R.R.S. Discovery II in May I950; $\times$, position of the Irish station SS.

Table III. Range of Temperatures and Salinities Recorded at the DeEp Stations Italicized on Fig. 8

$\begin{array}{ccc}\begin{array}{c}\text { Depth } \\ \text { (m.) }\end{array} & \begin{array}{c}\Delta T \\ \left({ }^{\circ} \mathrm{C} .\right)\end{array} & \begin{array}{c}\Delta S \\ (\%)\end{array} \\ 2000 & 0.6 & 0.09 \\ 2500 & 0.3 & 0.07 \\ 3000 & 0.1 & 0.04 \\ 3500 & 0.05 & 0.04\end{array}$


(ii) Although Dr H. Thomsen and Dr A. Fr. Bruun, the skilful observers who made the analyses at sea on board Dana, make no high claim for the accuracy of their inorganic phosphate analyses, an error of greater than $\pm 0 \cdot \mathrm{I} \mu \mathrm{g}$.-atom $/ 1$. seems unlikely.

(iii) The salt error correction factor is not a true constant, but only a factor less than I.I could make the deep water results consistent. Such a factor was highly unlikely.

Table IV. Vertical Distribution of Phosphorus ( $\mu$ G.-Atom/L.) IN THE BAY OF BISCAY IN I930 AND I950. INORGANIC PHOSPHATE OR Total Phosphorus

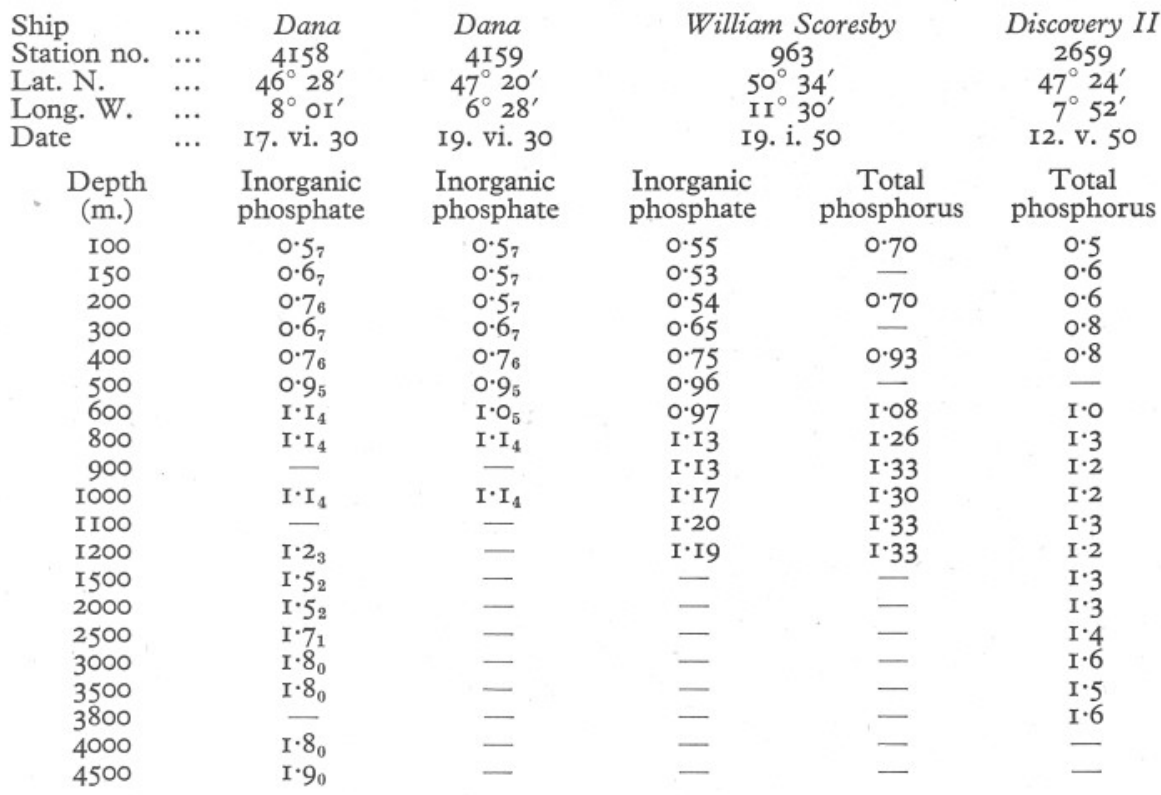

(iv) The Dana results at stations 4I58 and 4I59 between 400 and $1200 \mathrm{~m}$. agree closely with the relatively accurate analyses for inorganic phosphate made 20 years later on William Scoresby samples from a position about 280 miles to the north-north-west (Table IV).

(v) The Dana results of a week earlier at station 4I49, II miles off Cape Espichel, Portugal, below the productive zone, lie within the range of variation of inorganic phosphate established in the neighbourhood by Bôto (I945; also in Cons. Int., Bull. Hydrogr. for I934) on the Portuguese research vessel Albacora 4 years later (Table V).

(vi) The Dana results in 1930 show a steady increase in inorganic phosphate at $1000-2000 \mathrm{~m}$. from the neighbourhood of Lisbon northwards to the border of the Celtic Sea (Table VI). 
(vii) The Discovery II results between 200 and I300 m. check well with the more accurate analyses of total phosphorus made on William Scoresby samples from a position about 280 miles to the north-north-west in the same year I950 (Table IV).

Table V. Comparison of Inorganic Phosphate Content (as $\mu$ G.-Atom/L.P) at DANA Station 4I49, i i Miles off Cape Espichel (NEAR Lisbon) With $A L B A C O R A$ Stations Within 22 MILES OF IT, AND WITH ALBACORA STATION $55^{8}$

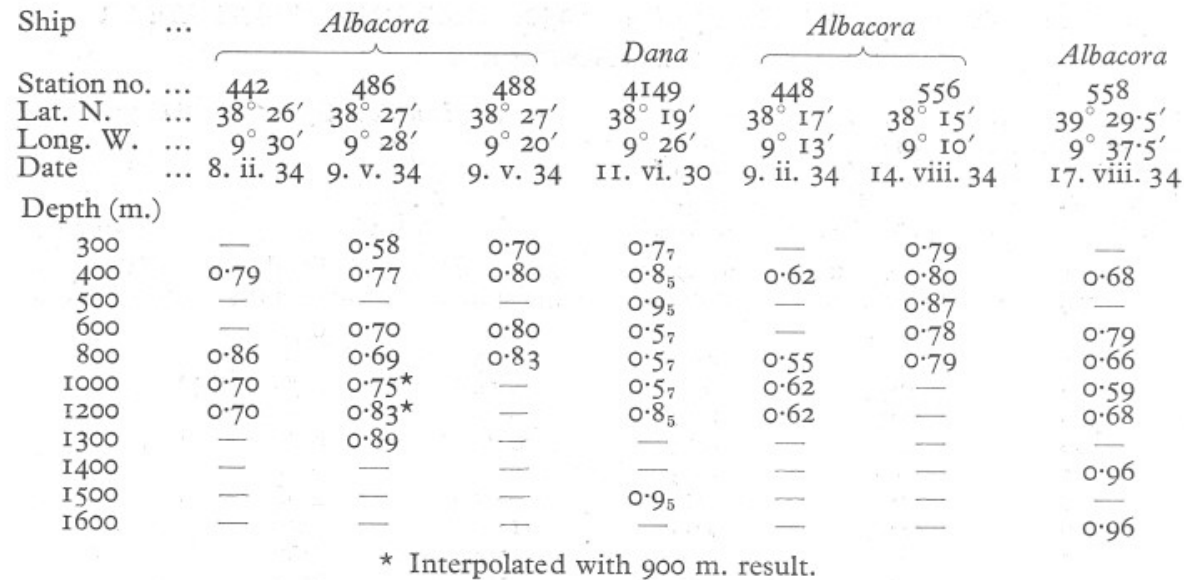

Table VI. Inorganic Phosphate (AS $\mu$ G.-Atom/L. P) at DanA Stations BeTWEen IOOO AND $2000 \mathrm{M}$. DePTH

\begin{tabular}{|c|c|c|c|c|c|}
\hline $\begin{array}{l}\text { Dana station } \\
\text { Lat. N. } \\
\text { Long. W. } \\
\text { Date }\end{array}$ & $\begin{array}{lc}\ldots & 4 \mathrm{I} 48 \\
\ldots & 37^{\circ} \mathrm{O}^{\prime} \\
\ldots & 9^{\circ} \mathrm{I}^{\prime} \\
\ldots & \text { II. vi. } 30\end{array}$ & $\begin{array}{c}4149 \\
3^{\circ} 19^{\prime} \\
9^{\circ} 26^{\prime} \\
\text { II. vi. } 30\end{array}$ & $\begin{array}{c}4 \mathrm{I} 56 \\
42^{\circ} 4 \mathrm{I}^{\prime} \\
9^{\circ} 49^{\prime} \\
\text { I6. vi. } 30\end{array}$ & $\begin{array}{c}45^{8} \\
46^{\circ} 28^{\prime} \\
8^{\circ} \mathrm{OI}^{\prime} \\
\text { I } 7 . \text { vi. } 30\end{array}$ & $\begin{array}{c}4159 \\
47^{\circ} 20^{\prime} \\
6^{\circ} 28^{\prime} \\
\text { I9. vi. } 30\end{array}$ \\
\hline \multicolumn{6}{|l|}{ Depth (m.) } \\
\hline $\begin{array}{l}1000 \\
1200 \\
1400 \\
1500 \\
1600 \\
2000\end{array}$ & $\begin{array}{l}0.6_{7} \\
0.7_{6} \\
0.9_{5} \\
- \\
\mathrm{I} \cdot 2_{4}\end{array}$ & $\begin{array}{l}0.5_{7} \\
0.8_{5} \\
- \\
0.9_{5} \\
-\end{array}$ & $\begin{array}{l}\mathrm{I} \cdot \mathrm{O}_{5} \\
\mathrm{I} \cdot \mathrm{O}_{5} \\
\overline{\mathrm{I} \cdot 3_{3}} \\
\frac{\mathrm{I} \cdot 3_{3}}{}\end{array}$ & $\begin{array}{l}\mathrm{I} \cdot \mathrm{I}_{4} \\
\mathrm{I} \cdot 2_{3} \\
-{ }^{2} \cdot 5_{2} \\
\frac{\mathrm{I} \cdot 5_{2}}{}\end{array}$ & $\begin{array}{l}\mathrm{I} \cdot \mathrm{I}_{4} \\
- \\
- \\
-\end{array}$ \\
\hline
\end{tabular}

(viii) It would seem therefore that in the northern Bay of Biscay in June I930 the phosphate content at I200-2000 $\mathrm{m}$. was higher than it is now in the same area or than it was then to the southward. Variations in phosphate content of at least $0.2 \mu \mathrm{g}$.-atom $/ 1$. have taken place. It may not be by chance that the decrease in the deep water has occurred at the same time as that in the English Channel near Plymouth. 
North Atlantic Central Water

According to Sverdrup et al. (I942, p. 668) North Atlantic Central water characterized by a nearly straight $T-S$ curve between $T=8^{\circ}, S=35 \cdot 10 \%$ and $T=19^{\circ}, S=36 \cdot 70 \%$ has been found over a very large area of the North Atlantic. In this area its presence has been masked below $10^{\circ}$ and above I I $\cdot 5^{\circ} \mathrm{C}$. Below $10^{\circ}$ its place is taken by Gulf of Gibraltar or cascade waters. Above II $\cdot 5^{\circ}$ we find the zone of strong seasonal variations, due to solar heating of the surface waters in summer and of vertical mixing in winter. Between these limits occurs water resembling the Central water but, rather surprisingly, somewhat warmer, and needing its own $T-S$ curve. This can be derived only from stations where oxygen determinations are available, such as stations $7-15$ of Armauer Hansen in I9I4. Those selected were:

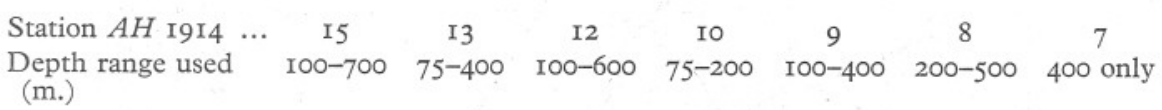

The linear $T-S$ curve so calculated is

$$
S=35 \cdot 50_{8}+0 \cdot 124(T-\text { II }) \text {. }
$$

The temperature and salinity of North Atlantic Central water below Ioo $\mathrm{m}$. depth brought into this area should comply with this relation (see Fig. 9).

\section{The Upper Limit of Central Water}

The upper limit of North Atlantic Central Water is the point where the $T-S$ curve ceases to follow equation (2). In winter and spring the upper waters are homogeneous, represented by a point, and in summer they are isohaline and represented by a vertical $T-S$ curve. In June I9I4 at the Armauer Hansen stations the upper limit was clearly definable within $25 \mathrm{~m}$. (Table VII).

\section{Table VII. The Upper Limit of North Atlantic Central Water at ARMAUER HaNSEN Stations is TO 6 IN JunE I9I4}

\begin{tabular}{|c|c|c|c|c|c|c|c|c|c|c|}
\hline Station & I5 & I4 & I3 & I2 & II & IO & 9 & 8 & 7 & 6 \\
\hline $\begin{array}{l}\text { Depth of upper } \\
\text { limit (m.) }\end{array}$ & 100 & 75 & 75 & 100 & c. 75 & $100^{\star}$ & 100 & 200 & 200 & $\begin{array}{c}\text { Not } \\
\text { present }\end{array}$ \\
\hline $\begin{array}{l}\text { Temperature } \\
\left({ }^{\circ} \text { C. }\right)\end{array}$ & I $2 \cdot 37$ & $12 \cdot 50$ & 12.59 & II.53 & II $\cdot 27$ & II 64 & II $\cdot 02$ & II IO & I0.93 & \\
\hline $\begin{array}{l}\text { Salinity (\%) } \\
\text { Oxygen (\%) }\end{array}$ & $\begin{array}{l}35 \cdot 69 \\
92\end{array}$ & $\begin{array}{l}35 \cdot 69 \\
93\end{array}$ & $\begin{array}{l}35 \cdot 72 \\
92 \cdot 5\end{array}$ & $\begin{array}{l}35 \cdot 59 \\
96\end{array}$ & $\begin{array}{l}35 \cdot 54 \\
98\end{array}$ & $\begin{array}{l}35 \cdot 57 \\
94\end{array}$ & $\begin{array}{l}35 \cdot 5 \mathrm{I} \\
96\end{array}$ & $\begin{array}{l}35 \cdot 55 \\
95\end{array}$ & $35 \cdot 53$ & \\
\hline
\end{tabular}

* High oxygen content (IO4\%) shows that the $75 \mathrm{~m}$. water belonged within the zone of winter mixing, not of Central Water.

From station 15 inwards to station 9, as at many other deep Atlantic stations, the limit of vertical mixing had been between 75 and $100 \mathrm{~m}$. depth (Fig. 9). Moreover, at the more seaward stations I5, I4 and I3, the winter surface water had had a salinity of about $35.70 \%$ and a temperature of $12.4^{-}$ I $2 \cdot 6^{\circ} \mathrm{C}$. Chemically it was essentially the same water as that underlying it. 


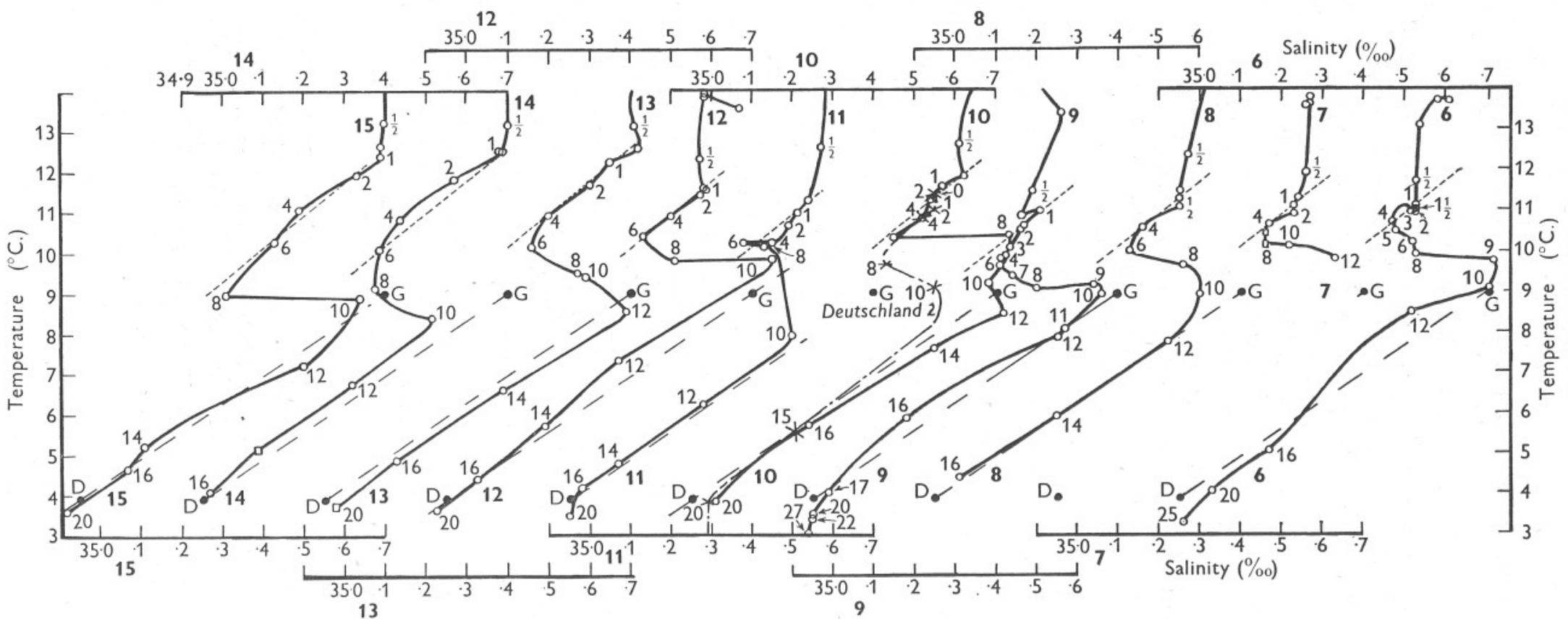

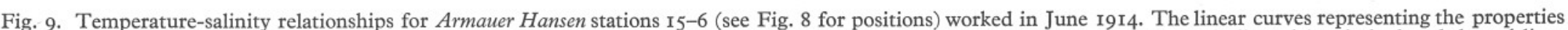
of mixed Gulf of Gibraltar and Deep water (equation I, p. 467) and North Atlantic Central water (equation 2, p. 479) are indicated by dashed and dotted lines respectively. Deutschland Reihe 2 is superimposed on Armauer Hansen station ro, from which it was distant about four miles. The points G and D represent the mean properties of Gulf of Gibraltar and North Atlantic Deep Water. The figures in bold-faced type denote station numbers, The remaining numbers against the curves denote depths of observations in hundreds of metres. 
Approaching the continental slope at stations 8, 7 and 6 the apparent depth of vertical mixing was more than twice as great (Fig. 9). Meteorological conditions at these stations cannot have differed greatly from those farther out, and one is forced to seek another origin for the upper $200-300 \mathrm{~m}$. of water with salinity between $35.5 \mathrm{I}$ and $35.55 \%$ and temperature between 10.9 and I $\cdot I^{\circ} \mathrm{C}$. We have to deal with a phenomenon peculiar to the neighbourhood of the continental slope (cf. Cooper, I952a).

\section{The Lower Limit of Central Water}

The lower limit of the North Atlantic Central water rises as the continental slope is approached (Table VIII).

\section{Table VIII. The Lower Limit of North Atlantic Central Water at ARMAUER HANSEN Stations I5 TO 6 IN June I9I4}

\begin{tabular}{|c|c|c|c|c|c|c|c|c|c|c|}
\hline Station & I5 & I4 & I3 & I2 & II & IO & 9 & 8 & 7 & 6 \\
\hline $\begin{array}{l}\text { Depth of lower } \\
\text { limit (m.) }\end{array}$ & 750 & 500 & 500 & 600 & $400 ?$ & $400 ?$ & 500 & 500 & 400 & $\begin{array}{c}\text { Not } \\
\text { present }\end{array}$ \\
\hline $\begin{array}{l}\text { Temperature } \\
\left({ }^{\circ} \mathrm{C} \text { ) }\right.\end{array}$ & $9 \cdot 35$ & 10.40 & 10.55 & $10 \cdot 34$ & 10.25 & 10.82 & 9.90 & 10.32 & 10.69 & \\
\hline $\begin{array}{l}\text { Salinity }(\%) \\
\text { Oxygen }(\%)\end{array}$ & $\begin{array}{l}35 \cdot 33 \\
\text { c. } 73\end{array}$ & $\begin{array}{l}355^{\circ} 4 \mathrm{I} \\
84\end{array}$ & $\begin{array}{l}35 \cdot 47 \\
82\end{array}$ & $\begin{array}{l}35 \cdot 43 \\
85\end{array}$ & $\begin{array}{l}35 \cdot 45 \\
85 \cdot 5\end{array}$ & $\begin{array}{l}35 \cdot 52 \\
86 \cdot 5\end{array}$ & $\begin{array}{l}35 \cdot 4 \mathrm{I} \\
84 \cdot 5\end{array}$ & $\begin{array}{l}35 \cdot 43 \\
8 \mathrm{I}\end{array}$ & $\begin{array}{l}35.47 \\
83\end{array}$ & \\
\hline
\end{tabular}

It extends down to $750 \mathrm{~m}$. at station 15 and only to $400 \mathrm{~m}$. at station 7 . At station 6 it is not recognizable in the midst of more highly oxygenated water. It was underlain either by a mixed water formed between itself and Gulf of Gibraltar water as at stations I5, I4, I3, I2, 9 and 8 or by cascaded water as at stations II, IO and 7 .

The stratum of Central water gets thinner as the slope is approached (Figs. 9 and II). At station I5 it was $700 \mathrm{~m}$. thick, whereas it was recognizable with certainty at station 7 only at $400 \mathrm{~m}$. Evidently, in June I9I4, the North Atlantic Central water had little direct effect on the Celtic Sea.

At the upper limit the Central water has an oxygen content $92-98 \%$ saturated, at the lower $8 \mathrm{I}-85 \%$. The high oxygen content $(99 \%)$ at stations 6 at $400 \mathrm{~m}$. shows that this was not Central but 'capsized' or cascaded water. The temperature, salinity and density were appropriate to Celtic Sea water the previous winter. The arrival of cascade water in the ocean abreast of the slope may bring about a state of labile or metastable equilibrium to a considerable depth. Winds, which can mix the waters of the open ocean only to 75-100 m., can therefore with the same ease homogenize the waters near the slope by a 'capsizing' process (Cooper, I952a) to a much greater depth.

\section{Submarine Valleys in the Continental Slope}

In February I949 a survey of an area around $48^{\circ} \mathrm{N}$. lat., $9^{\circ} 30^{\prime} \mathrm{W}$. long. was carried out in good weather by the present Hydrographer of the Navy, Rear-Admiral A. Day, C.B.E., D.S.O., when in command of H.M. Surveying 
Ship Dalrymple. The whole survey, based on a floating beacon anchored near the $100 \mathrm{fm}$. line and fixed by a series of star sights, was achieved by echosounding checked by the lead at intervals. A portion of the resulting document has been reproduced here (Fig. IO) by permission of the Hydrographer of the Navy.

If the sea-level were to fall by several hundred fathoms, a ria coast of strong relief would stand revealed. Thus the submarine valley at $48^{\circ} 13^{\prime} \mathrm{N} ., 9^{\circ} 2 \mathrm{I}^{\prime} \mathrm{W}$. cuts back for about 9 sea miles $(17 \mathrm{~km}$.) and sections across it show that the maximum depth of the valley bottom below the containing spurs is about I $800 \mathrm{ft}$. $(550 \mathrm{~m}$.).

The French research vessel Président Théodore Tissier (Beaugé, 1934) has charted the continental slope between $48^{\circ}$. $10^{\prime} \mathrm{N}$. lat., $9^{\circ} 20^{\prime} \mathrm{W}$. long. and $49^{\circ} 00^{\prime} \mathrm{N}$. lat., $\mathrm{II}^{\circ} \mathrm{Io} \mathrm{o}^{\prime} \mathrm{W}$. long. I am much indebted to Monsieur P. Desbrosses for presenting me with a copy of this chart. The area surveyed was much greater and the density of soundings would seem to have been less, possibly considerably less, than in Dalrymple's survey so that the contoured chart is likely to be less accurate in detail than that reproduced in Fig. Io. However, great detail is not necessary to show that to the west-north-west there are a number of submarine canyons of even greater size. Thus the steep cliff shown in Fig. Io (top left) would appear to be one jaw of a canyon about 15 miles long and with a maximum depth between and below the containing spurs of about $4000 \mathrm{ft}$. This canyon and others appear to be ideally shaped to create submarine eagres whilst the broad spurs shown in Fig. Io and two similar ones at $48^{\circ} 40^{\prime} \mathrm{N}$., $10^{\circ} 22^{\prime} \mathrm{W}$. and $48^{\circ} 35^{\prime} \mathrm{N}$., $10^{\circ} \mathrm{IO} \mathrm{O}^{\prime} \mathrm{W}$. appear likely to exacerbate the capsizing process suggested as occurring in southerly gales all along the continental slope. Continuous and extensive observations over these submarine canyons would be needed before well-placed standard hydrographical stations off the continental slope between 6 and $\mathrm{II}^{\circ} \mathrm{W}$. can be proposed.

\section{The Vertical Distribution of Water Masses}

Making use of the extensive information to be gleaned from Fig. 9 and from the sections and plots for temperature, salinity and density by Helland-Hansen \& Nansen (1927, table II and plates I4 and 32) and from those for oxygen by Gaarder (I927, pp. 9-I4, and Schnitt I $a$ and $b$ ), it is possible to identify the several water masses in the Armauer Hansen section in June 1914 (Fig. II). It is not possible to assess the importance of internal waves in causing the undulating boundaries, particularly of the Gulf of Gibraltar water. At station II this was completely squeezed out so that the Celtic Cascade Core (see below) and the Mixed Gibraltar-Deep water were in contact.

Station I5 was a typical and simple oceanic station with North Atlantic Central and Gulf of Gibraltar water clearly developed.

Stations II and Io exhibited marked idiosyncrasies. At $800 \mathrm{~m}$. at station II 
and at $600 \mathrm{~m}$. at station Io was a core of highly oxygenated water (Table IX, italicized), having properties appropriate to the north-western Celtic Sea the previous winter. There is little doubt that it had recently cascaded and had been forced out into the ocean as a core (cf. Cooper \& Vaux, I949), having been canalized in a submarine valley such as those shown in Fig. Io. The

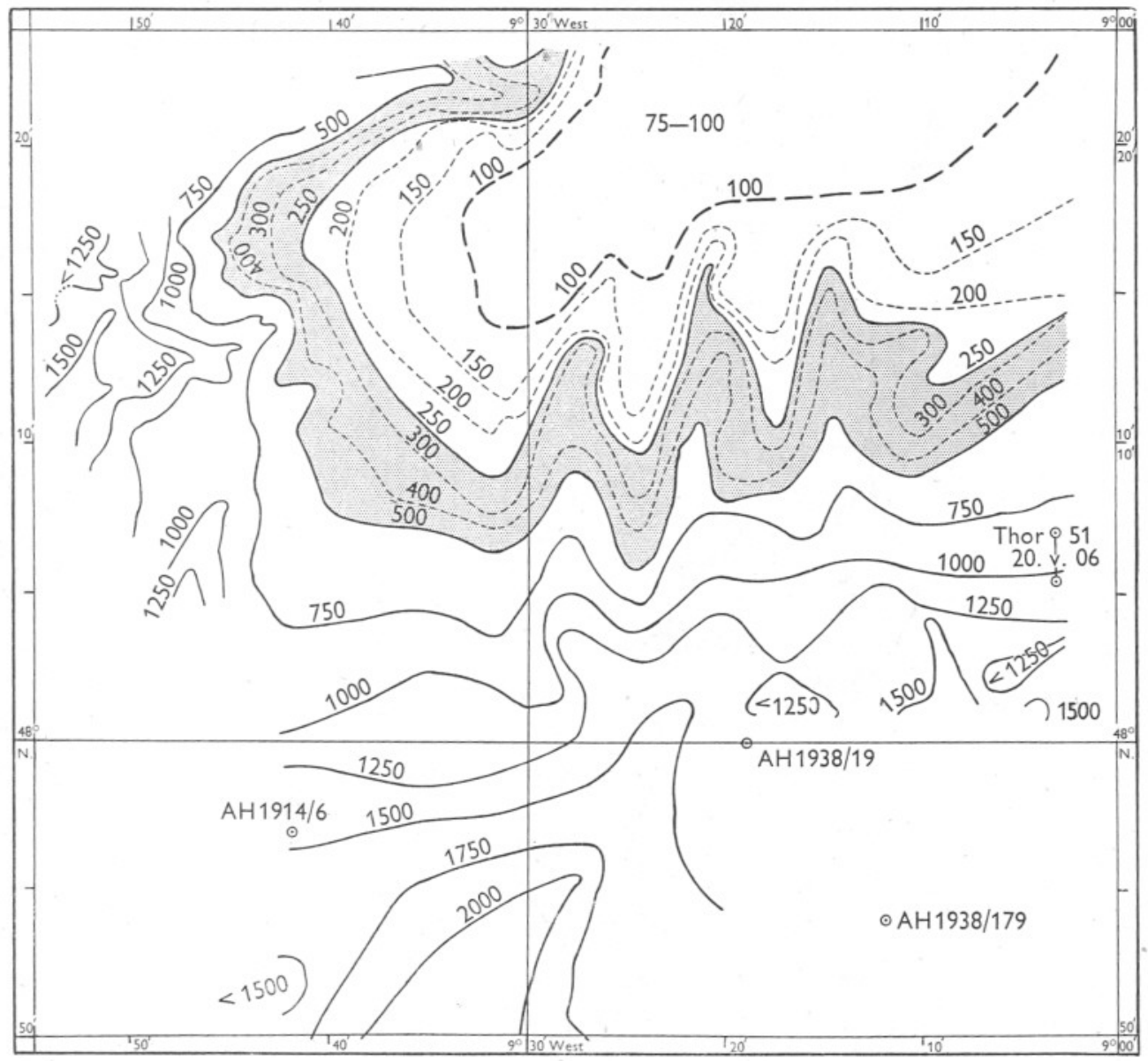

Fig. Io. Contoured bottom topography of the continental slope of the Celtic Sea in the neighbourhood of $48^{\circ} \mathrm{N}$. lat., $9^{\circ} 30^{\prime} \mathrm{W}$. long., making use, by permission of the Hydrographer of the Navy, of an original hydrographic survey carried out by H.M. Surveying Ship Dalrymple (Captain, now Rear-Admiral A. Day, C.B.E., D.S.O.) in February I949. South of $48^{\circ} \mathrm{N}$. lines of soundings are comparatively few. The contours at 250 and $1750 \mathrm{fm}$. have been added by the author. The $100 \mathrm{fm}$. contour is shown by a thick broken line. Contours at $250 \mathrm{fm}$. intervals are shown by thick continuous lines. Intermediate contours at $50 \mathrm{fm}$. intervals from 100 to $300 \mathrm{fm}$. and at $400 \mathrm{fm}$. are shown by thin dotted lines. The slope between the 250 and $500 \mathrm{fm}$. contours is stippled. The positions of the important station 6 worked by Armauer Hansen in June I9I4 and of two stations worked by the same ship in 1938 are shown. The position of station 5I, worked by Thor on 20 May 1906, is marked by an open circle, together with the adjustment necessary to bring the sounding reported by Thor into line with the chart. 


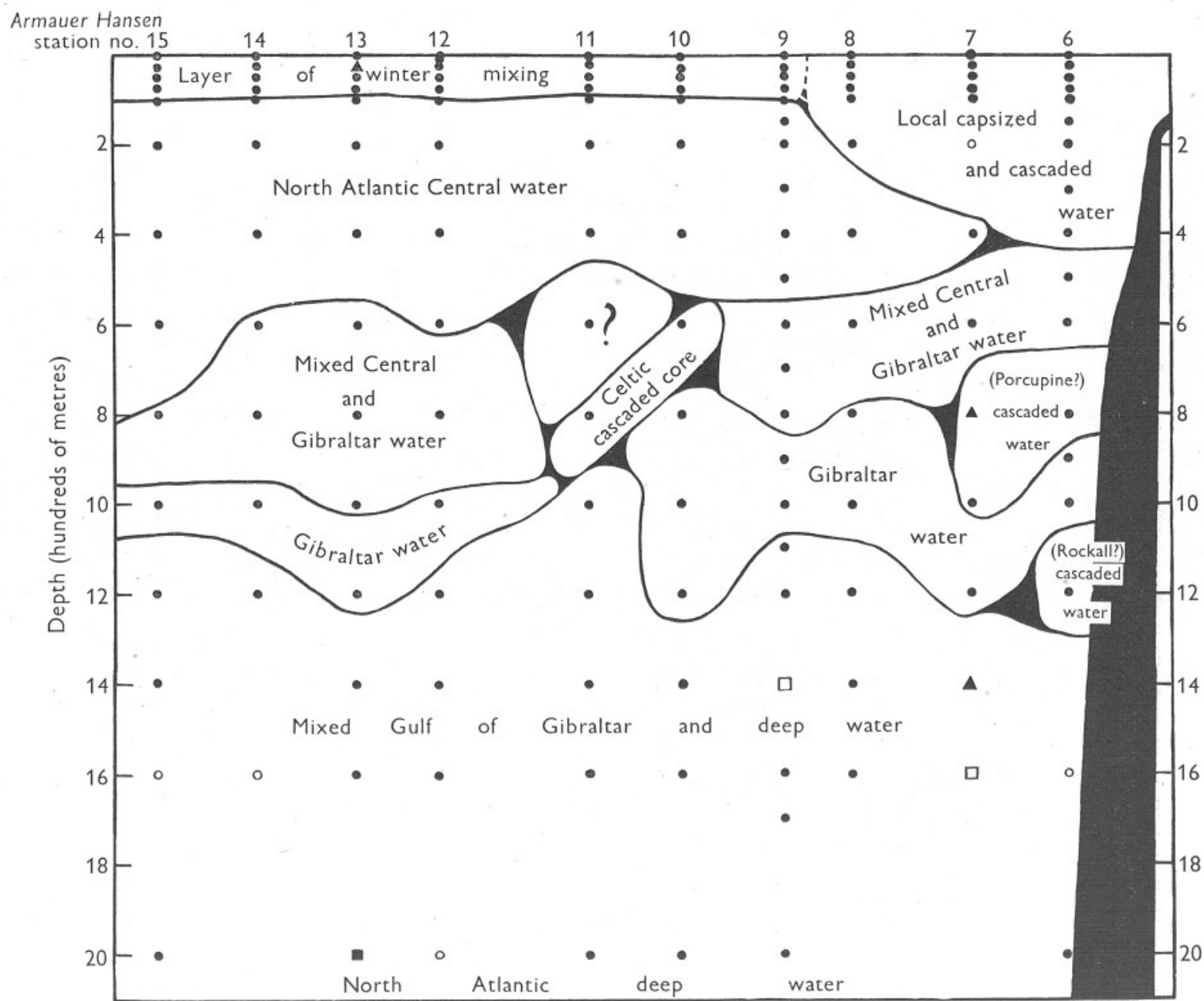

Fig. II. Section illustrating distribution of water masses at Armauer Hansen stations 15-6, June I9I4. Circles represent determinations of temperature and salinity, squares represent determinations of temperature only, and triangles of salinity only. Where oxygen determinations were also made these symbols are blacked in. Helland-Hansen and Nansen's interpolated results at intermediate depths have been used in constructing the section. 
stability at the base of the core $\left(\Delta \sigma_{t} 0.4 \mathrm{I}\right.$ in $200 \mathrm{~m}$.) was remarkable. The core almost certainly originated north of the Armauer Hansen section, so that the fact that the oxygen-rich water lay deeper at the outer station no. I I than at no. Io agrees with a thesis, propounded by Sandström (I9I8, p. 24I) and confirmed by other work at Plymouth, that such currents move forward in the northern hemisphere with a right-handed-screw motion.

The position of station Io was within 5 miles of that of Deutschland Reihe 2 $\left(46^{\circ} 29^{\prime} \mathrm{N}\right.$., I3 ${ }^{\circ} \mathrm{II}^{\prime}$ W. $)$ on I6 May I9I I, the temperature-salinity relation for which has been superimposed on Fig. 9 (Station 10) as a fine dashed and dotted line. The nature of the water masses on the two occasions differed greatly but, unfortunately, no depth was worked between 400 and $800 \mathrm{~m}$. or between 1000 and $1500 \mathrm{~m}$.

Table IX. Core of Celtic Sea Cascade Water observed by ARMAUER HANSEN ON 7 JUNE I9I4

\begin{tabular}{|c|c|c|c|c|c|c|}
\hline \multirow{2}{*}{$\begin{array}{l}\text { Depth } \\
\text { (m.) }\end{array}$} & \multicolumn{2}{|c|}{ Oxygen } & \multirow{2}{*}{$\underset{(\%)}{\text { Salinity }}$} & \multirow{2}{*}{$\begin{array}{l}\text { Temp. } \\
\left({ }^{\circ} \mathrm{C} .\right)\end{array}$} & \multirow{2}{*}{$\underset{\sigma_{t}}{\text { Density }}$} & \multirow[b]{2}{*}{ Nature of water } \\
\hline & (cc./1.) & $\%$ & & & & \\
\hline \multicolumn{7}{|c|}{ Station II, $46^{\circ} \circ 0^{\prime} \mathrm{N} ., 4^{\circ} \circ 3^{\prime} \mathrm{W}$} \\
\hline 400 & 5.45 & $85 \cdot{ }_{5}$ & $35 \cdot 45$ & $10 \cdot 25$ & $27 \cdot 28$ & North Atlantic Central \\
\hline 600 & 4.83 & $76^{\circ}$ & $35 \cdot 38$ & $10 \cdot 24$ & $27 \cdot 22$ & \\
\hline 800 & 5.48 & 86 & $35 \cdot 43$ & $10 \cdot 17$ & $27 \cdot 28$ & Celtic Cascade Core \\
\hline IOOO & 4.55 & 68 & $35 \cdot 50$ & $7 \cdot 95$ & $27 \cdot 69$ & Mixed Gulf of Gibraltar and Deep \\
\hline \multicolumn{7}{|c|}{ Station Io, $46^{\circ} 25^{\prime}$ N., $13^{\circ} \mathrm{I} 4^{\prime} \mathrm{W}$} \\
\hline 400 & $5 \cdot 44$ & $86 \cdot{ }_{5}$ & $35 \cdot 52$ & 10.82 & $27 \cdot 23$ & North Atlantic Central \\
\hline 600 & 6.01 & $94^{\circ}$ & $35 \cdot 45$ & $10 \cdot 36$ & $27 \cdot 26$ & Celtic Cascade Core \\
\hline 800 & $4 \cdot 07$ & $64 *_{5}^{\circ}$ & $35 \cdot 73$ & I0. 44 & $27 \cdot 48$ & Gulf of Gibraltar \\
\hline 1000 & $4 \cdot 38$ & $67{ }^{\circ}$ & 35.68 & $9 \cdot 25$ & 27.63 & Gulf of Gibraltar \\
\hline
\end{tabular}

At station 6 against the slope, North Atlantic Central water was not recognizable and only vestigially at $400 \mathrm{~m}$. at station 7 . Gulf of Gibraltar water was present strongly at 900-1000 m. at station 6 and at $1200 \mathrm{~m}$. at station 7 .

Also at station 6 oxygenated water was banked against the slope in three separate strata. That above $400 \mathrm{~m}$. depth was largely a mixed water formed by cascading from the continental shelf and by capsizing over the continental slope. For the highly oxygenated water at $800 \mathrm{~m}$., there may be no need to seek an origin farther north than cascade water from the Porcupine Bank. That at I200 m., beneath the Gulf of Gibraltar water, may have cascaded from the neighbourhood of the Rockall Table Mount, an event which will be further discussed below (p. 497, and Table XVIII). To these several water masses of very different histories but similar salinities, it is considered very probable that some organisms may react very differently, particularly at sensitive stages in their life histories, such as development of diatom resting spores, fertilization and hatching of eggs and moulting of crustaceans (cf. Wilson, I95I). Therefore, when discussing the hydrographical background of biological events it is never sufficient to speak of 'an influx of Atlantic Water'. The particular kind of Atlantic water needs to be identified. 


\section{Results of the InTERnational Gulf Stream Expeditions I938}

In June 1938 a section with stations 20 miles apart was worked by the Danish research vessel Dana from $51^{\circ} 33^{\prime}$ N., $10^{\circ} 22^{\prime} \mathrm{W}$. off Dursey Head, County Kerry, to $53^{\circ} 48^{\prime}$ N., $20^{\circ} 21^{\prime}$ W. (Fig. 8) (Cons. Int., Bull. Hydrogr. for I938). The section crossed the submarine indentation and the southern spur of the Porcupine Bank into the deeper Eastern North Atlantic. The distribution of properties was complex and their interpretation will be difficult. Two similar but less complex sections were worked at the same time by the Norwegian vessel Armauer Hansen, south-west from the English Channel towards the Azores. No advantage is to be gained by a superficial examination of these valuable observations. Their application to our problems, especially to the Celtic Sea mackerel investigations in the same year, is deferred until the Scandinavian oceanographers have published their conclusions.

\section{The Slope Waters off the Celtic Sea in i950}

On I8-I9 January I950, R.R.S. William Scoresby worked four stations along the parallel $50^{\circ} 34^{\prime} \mathrm{N}$. between $10^{\circ} 40^{\prime}$ and $I I^{\circ} 30^{\prime} \mathrm{W}$. (Fig. 8), where the results of the Irish investigations at station SS ( $50^{\circ} 34^{\prime} \mathrm{N}$., $\mathrm{II}^{\circ} \mathrm{I} 7^{\prime} \mathrm{W}$.) had shown that vertical exchanges occur. Later, on I I-I2 May, R.R.S. Discovery II worked a line of three stations (section D II) over the slope between $48^{\circ}$ I $8^{\prime} \mathrm{N}$., $7^{\circ} 30^{\prime} \mathrm{W}$. and $47^{\circ} 24^{\prime} \mathrm{N}$., $7^{\circ} 52^{\prime} \mathrm{W}$., the deepest being sampled to $3800 \mathrm{~m}$. depth. She worked other stations on the shelf, which will be discussed in a later paper. Cordial thanks are due to Dr G. E. R. Deacon, F.R.S., and to Dr N. A. Mackintosh for arranging this co-operation, to Dr T. J. Hart and Dr H. P. F. Herdman, scientists in charge of the two ships, and to $\mathrm{Mr}$ R. I. Currie and $\mathrm{Mr} \mathrm{H}$. Cox, who were responsible for collecting many of the samples, and to Mr Currie for the analyses of oxygen. The results are presented graphically in Figs. I2-I5.

The vertical variations in salinity and temperature between the surface and I200 m. depth (Fig. I2) are smaller than in most parts of the world, but are characteristic of the waters bathing the Western European continental slope between Gibraltar and Western Ireland. Within this framework there is a very marked difference in the nature of the water masses encountered on the two cross-slope sections.

\section{The Surface Waters}

On the northern section worked by R.R.S. William Scoresby on I8-I9 January I950 vertical mixing was apparent down to $250 \mathrm{~m}$., as on the Armauer Hansen section in June I9I4 (Figs. 9, I2 and I3, panel 3). Along the 33-mile long section the distribution of density above $250 \mathrm{~m}$. depth was almost uniform $\left(27.05-27\right.$. II $\left.\sigma_{t}\right)$, indicating very sluggish water movements parallel to the 
continental slope and the results of capsizing. None the less the total phosphorus content showed a horizontal increase westward of about $0 \cdot \mathrm{I} \mu \mathrm{g}$.-atom/1. as the brim of the slope was crossed (Fig. I3, panel 4). Again, in spite of the generally vertically uniform temperature distribution, there were small density inversions which appear to be real at 20, I50 and $300 \mathrm{~m}$. (Fig. I2). This phenomenon, frequently observed in this neighbourhood, will be discussed in another paper.

The content of nutrients at the easternmost station WS960 $\left(50^{\circ} 34^{\prime} \mathrm{N}\right.$., $10^{\circ} 40^{\prime} \mathrm{W}$.; total phosphorus $0.6 \mathrm{I}-0.63$, inorganic phosphate $0.48-0.53 \mu \mathrm{g}$.atom/1. P) suggested that some areas of the northern Celtic Sea were little richer than the English Channel.

The phosphate content on I9 February 1927 at position SS, determined by Atkins (I928), may be compared with that at the same position and depths interpolated from stations WS 962 and 963 (Table X).

\section{TABLE X}

$\begin{array}{ccc}\begin{array}{c}\text { Depth } \\ \text { (m.) }\end{array} & \text { I9 February } & \text { I8-I9 January } \\ 0 & \text { I927 } & \text { I950 } \\ 402 & 0.46 & 0.55 \\ 860 & 0.72 & 0.73 \\ & 0.91 & \text { I. I3 }\end{array}$

The difference between the two water masses on the sections worked by R.R.S. William Scoresby in the north and R.R.S. Discovery II in the south shows up most clearly on a temperature-salinity diagram (Fig. I5). At no depth are the two waters closely related.

Along the southern (D II) section in May there was no relict isothermal, isopycnal layer remaining to indicate the lower limit of vertical mixing during the winter. It is unlikely that it extended down to $300 \mathrm{~m}$. The contents of total phosphorus and of silicate-Si of the uppermost I00 m. $(0.3-0.6$ and $0.5-2 \cdot 2 \mu \mathrm{g}$.-atom/1. respectively (Fig. I4, panels 4 and 5) were or had become low. It is probable that the relatively nutrient-rich winter surface water here (which should have been created by the gales of the first week of February) had been replaced by impoverished surface water from the ocean to the south or from the Biscayan shelf. If later such water moved into the English Channel it could bring only poor conditions with it.

In the southern section in May there was a density gradient (Fig. I4, panel 3). Assuming only horizontal water movements, this would indicate a weak eastbound current flowing along the edge of the slope, in agreement with the current system already deduced for the region by Helland-Hansen and Nansen (1927); but since vertical currents and internal waves may also have played a part no firm conclusion is possible. At least it seems that the impoverished warm saline surface water is more likely to have come from the ocean to the south-west or west than from the Biscayan shelf to the south-east. 


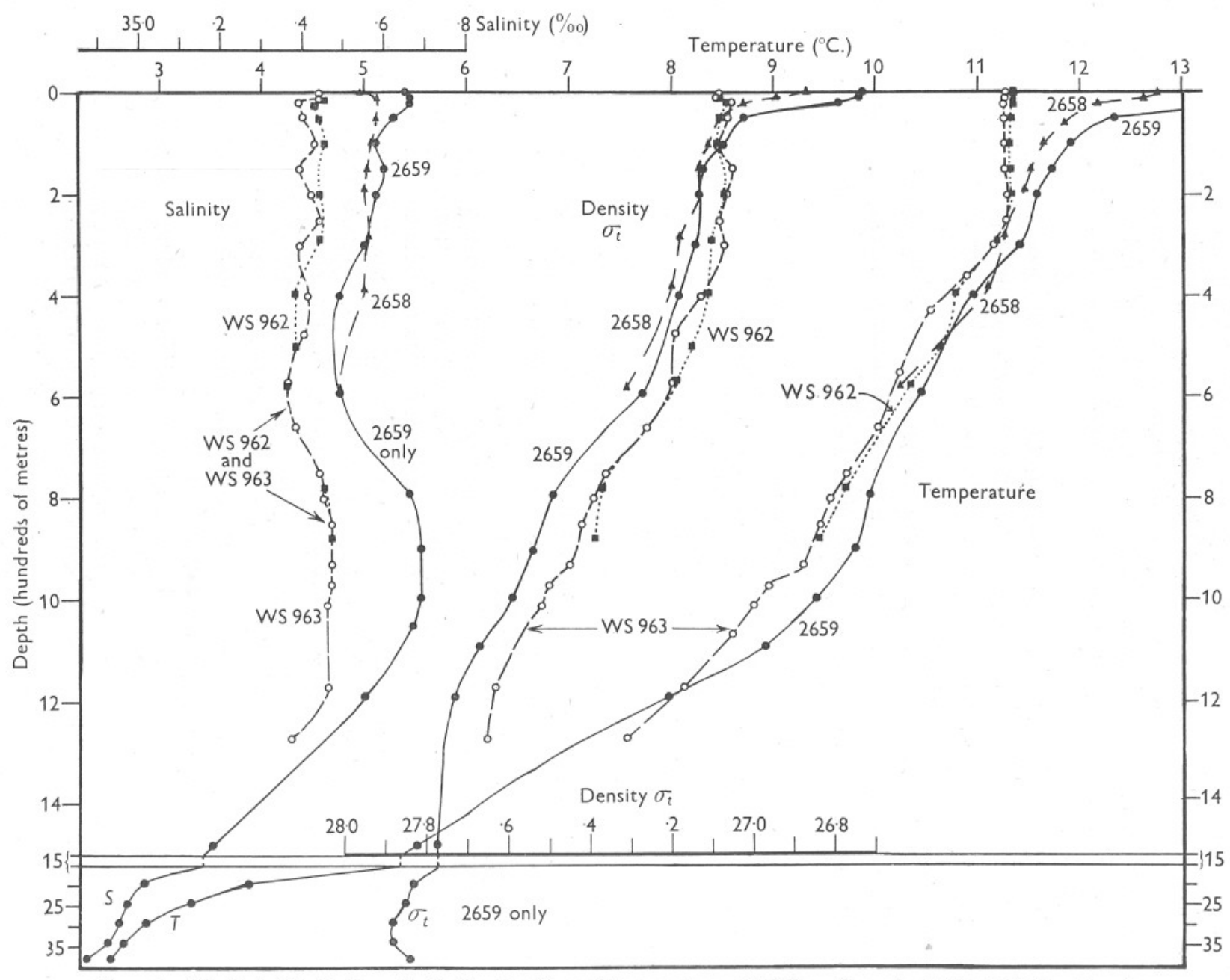

Fig. 12. Vertical distribution of salinity, density and temperature at William Scoresby stations $962(\cdots) \cdots)$, 963 (---O---) on I8-19 January I950, and Discovery II stations 2658 (- - $\mathbf{\Delta -}-$ ) and $2659(\longrightarrow)$ on II-12 May 1950. 


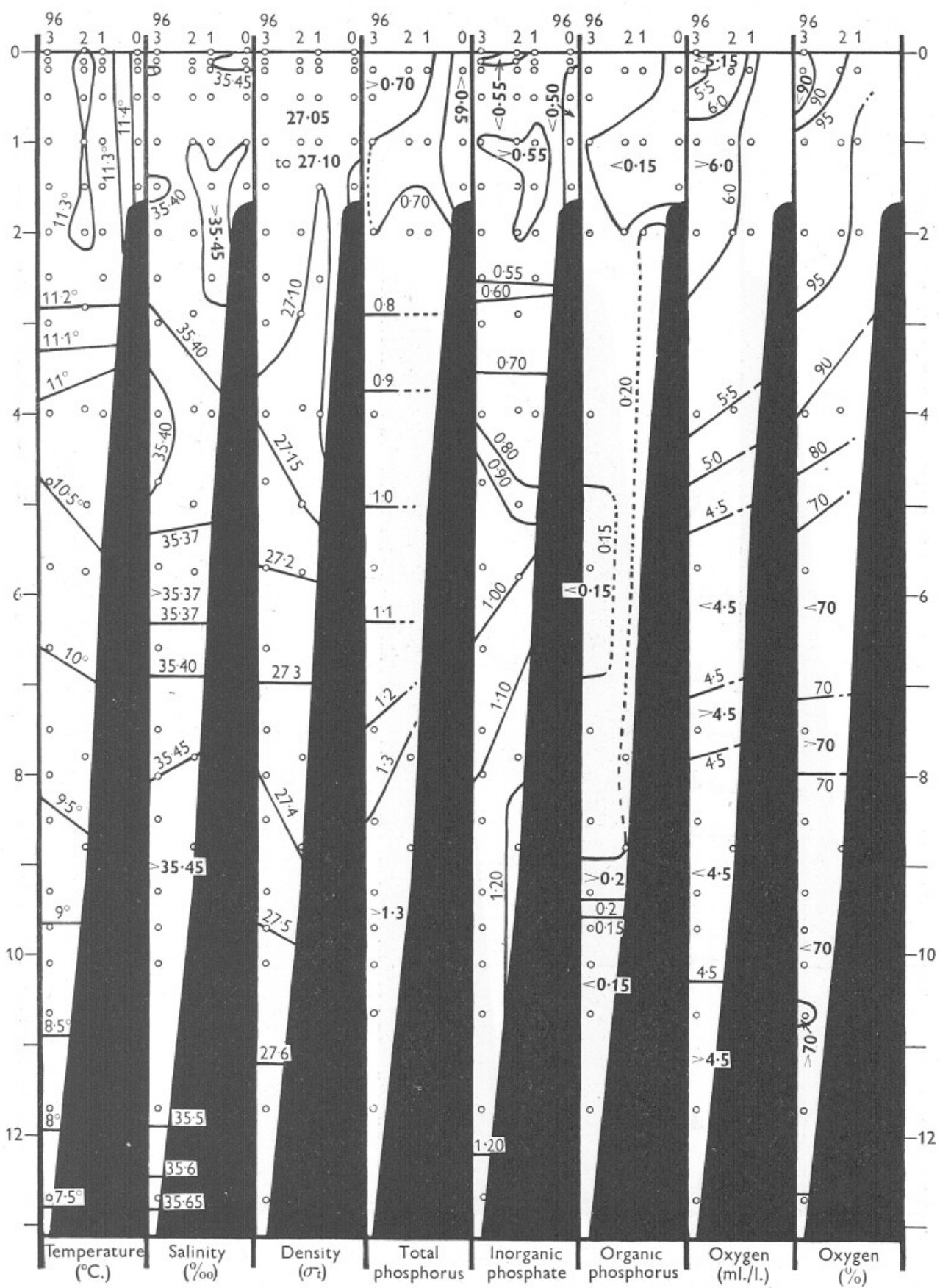

Fig. I3. Sections worked by R.R.S. William Scoresby on I8-I9 January 1950, illustrating the distribution of properties over the continental slope west of the Celtic Sea along the parallel of latitude $50^{\circ} 34^{\prime} \mathrm{N}$. Phosphorus and phosphate in $\mu \mathrm{g}$.-atom/1. P. Depths in hundreds of metres. 


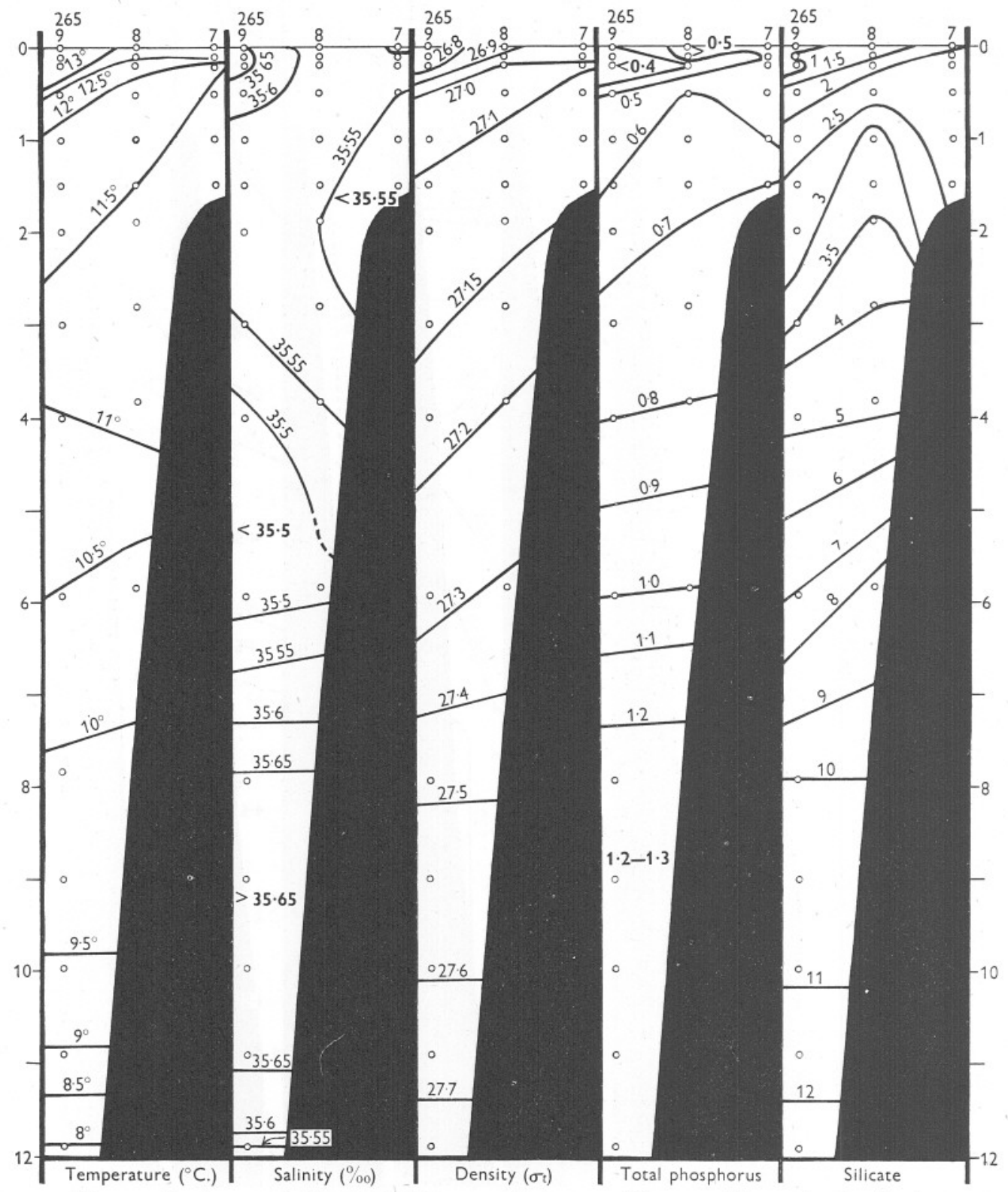

Fig. I4. Sections worked by R.R.S. Discovery II on I I-I2 May I950, illustrating distribution of properties over the continental slope south of the Celtic Sea approximately along the meridian $7^{\circ} 40^{\prime} \mathrm{W}$. Phosphorus and silicate in $\mu \mathrm{g}$.-atom $/ 1$. Depths in hundreds of metres. 


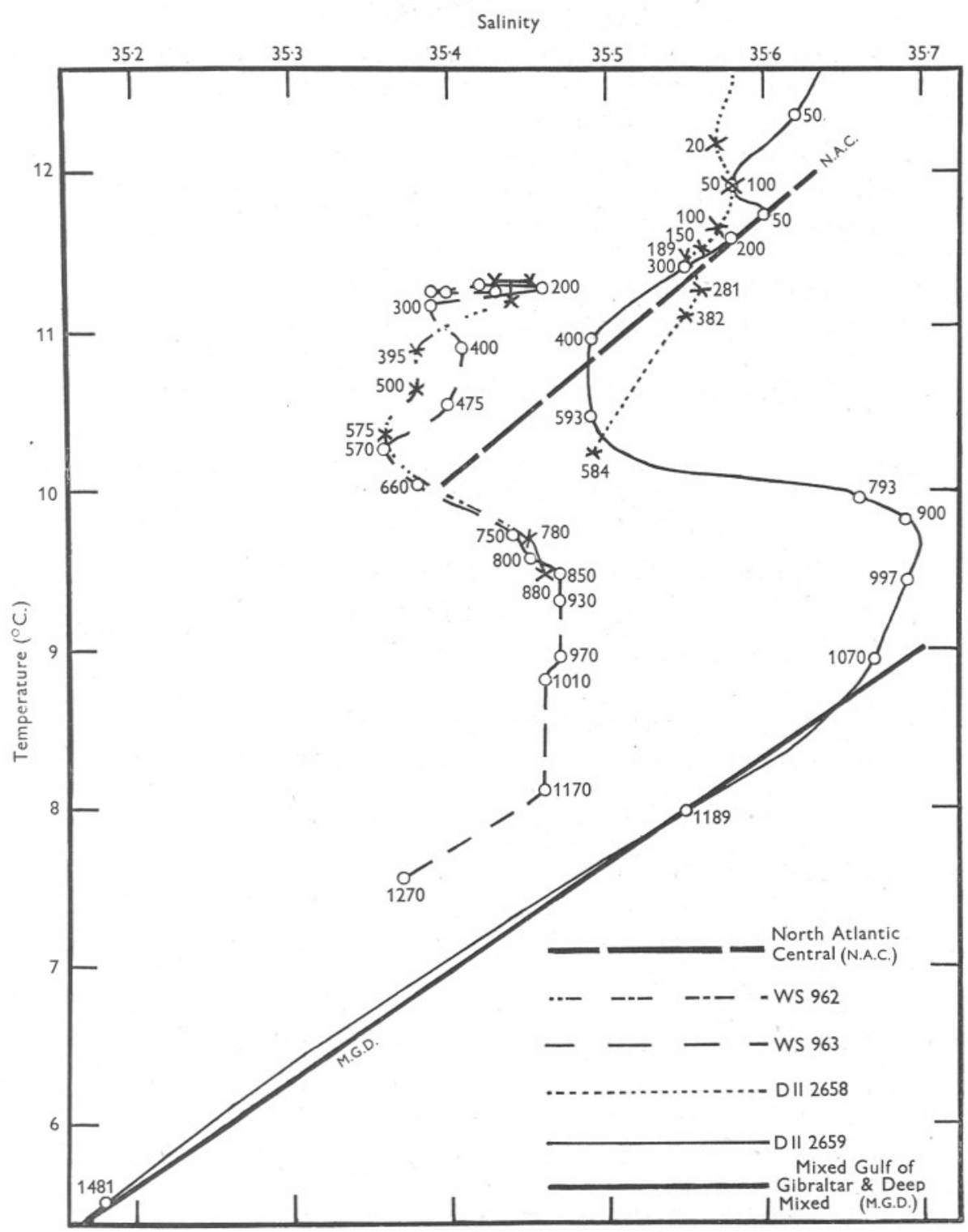

Fig. 15. Temperature-salinity relationships for the two William Scoresby stations $(962,963)$ and the two Discovery II stations $(2658,2659)$ over the continental slopes of the Celtic Sea in 1950. 


\section{The Deeper Waters}

On the southern section in May, the salinity maximum at around $1000 \mathrm{~m}$., characteristic of the Gulf of Gibraltar water, was well developed (Fig. I4, panel 2). It was also recognizable on the northern section in January. It had the properties set out in Table XI.

Determinations of silicate, in addition to those of oxygen, are likely to assist in distinguishing deep cascaded water from Gulf of Gibraltar water. Silicate determinations are also likely to distinguish cascaded from capsized water.

Above the Gulf of Gibraltar water lay water of minimum salinity and having the properties set out in Table XII.

Table Xi. Properties of the Gulf of Gibraltar Water in the EARLY MONTHS OF I950

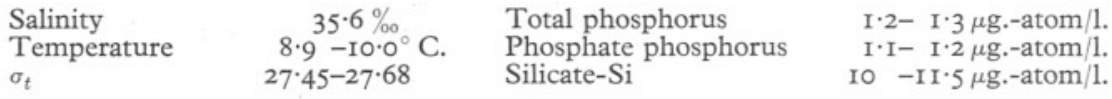

Table XII. Properties of Minimum Salinity Water

Salinity Temperature $\sigma_{t}$

\begin{tabular}{|c|c|}
\hline $\begin{array}{c}35.49 \% \\
10.25-10.95{ }^{\circ} \mathrm{C} .\end{array}$ & $\begin{array}{l}\text { Total phosphorus } \\
\text { Silicate-Si }\end{array}$ \\
\hline
\end{tabular}

$0 \cdot 6-\mathrm{I} \cdot 0 \mu \mathrm{g}$.-atom $/ 1$. $4 \cdot 8-8 \cdot 3 \mu$ g.-atom $/ 1$.

Table XIII. Some predicted Properties of the Several Types of Water Mass found near the Continental Slope of the Celtic Sea

\begin{tabular}{|c|c|c|c|c|c|}
\hline & $\begin{array}{c}\text { Oxygen } \\
(\%)\end{array}$ & $\begin{array}{c}\text { Silicate-Si } \\
(\mu \mathrm{g} \text {-atom/1.) }\end{array}$ & $\begin{array}{c}\text { Total } \\
\text { phosphorus } \\
(\mu \text { g.-atom } / 1 .)\end{array}$ & $\begin{array}{c}\text { Temperature } \\
\left({ }^{\circ} \mathrm{C} .\right)\end{array}$ & $\underset{(\%)}{\text { Salinity }}$ \\
\hline Cascaded water & $>85$ & $<4$ & $<0.7$ & $\begin{array}{l}\text { Uniform and } \\
\text { dependent on } \\
\text { origin }\end{array}$ & $\begin{array}{l}\text { Uniform and } \\
\text { dependent on } \\
\text { origin }\end{array}$ \\
\hline Capsized water & $\begin{array}{l}\text { High and } \\
\text { uniform }\end{array}$ & c. 6 & c. 0.9 & $\begin{array}{l}\text { Uniform and } \\
>\text { IO }\end{array}$ & $\begin{array}{l}\text { Uniform and } \\
>35.5\end{array}$ \\
\hline $\begin{array}{l}\text { Gulf of Gib- } \\
\text { raltar water }\end{array}$ & $65-69$ & IO-II.5 & $I \cdot 2-I \cdot 3$ & $9.0 \pm 0.5$ & $\begin{array}{l}\text { Maximal and } \\
>35.5\end{array}$ \\
\hline $\begin{array}{l}\text { Deeper North } \\
\text { Atlantic } \\
\text { Central water }\end{array}$ & $65-70$ & $>$ 10 & $>1 \cdot 3$ & $\begin{array}{l}\text { Conforming to } \\
\text { standard } T-S \\
\text { diagram }\end{array}$ & $\begin{array}{l}\text { Conforming to } \\
\text { standard } T-S \\
\text { diagram }\end{array}$ \\
\hline
\end{tabular}

The rapid increase in nutrient content through the layer of minimum salinity is very striking.

The low-salinity component of this water can come neither from above nor below. It can arise only by lateral mixing. Two origins are possible, either North Atlantic Central water from much the same depth to the south-west, or cascaded water directly from the Porcupine Bank or round by the South Porcupine submarine promontory from the Hebridean continental shelf. At William Scoresby station 963 on I9 January 1950 the low oxygen content 
$\left(63 .{ }_{5} \%\right.$ saturated) at the salinity minimum at $575 \mathrm{~m}$. indicates surely that then North Atlantic Central water was dominant there.

The predicted properties set out in Table XIII will certainly be modified in detail by further knowledge. They are meant to show how, by combining several determinations, it should become possible in this area to recognize with certainty the several water masses and admixtures of them.

\section{The Hydrography of the Submarine Indentation South of the Porcupine Bank and SOUth-west of COUnTy KerRy}

On twenty-seven occasions the Irish Fisheries Service, under the direction of the late $\mathrm{Mr}$ G. P. Farran, has made observations at the station SS $\left(50^{\circ} 34^{\prime} \mathrm{N}\right.$., $\mathrm{II}^{\circ} \mathrm{I} 7^{\prime} \mathrm{W}$. approximately) on the eastern side of the submarine indentation

Table XIV. Observations at the Irish Station SS, $50^{\circ} 34^{\prime}$ N., II ${ }^{\circ}$ I $^{\prime}$ W. APPROXIMATELY

\begin{tabular}{|c|c|c|c|c|c|}
\hline Station no. & $\begin{array}{l}\text { Lat. } \\
50^{\circ} \text { N. }+\end{array}$ & $\begin{array}{l}\text { Long. } \\
\text { II }^{\circ} \mathrm{W} .+\end{array}$ & Date & $\begin{array}{l}\text { Depth to } \\
\text { bottom } \\
\text { (m.) }\end{array}$ & $\begin{array}{l}\text { Depth of samples taken } \\
\text { below } 601 \mathrm{~m} \text {. }\end{array}$ \\
\hline $\begin{array}{l}\text { SR } 992 \\
\text { SR rog8 }\end{array}$ & $34^{\prime}$ & $\begin{array}{l}29^{\prime} \\
16^{\prime}\end{array}$ & $\begin{array}{l}\text { 9. viii. I0 } \\
\text { II/I2. ii. I I }\end{array}$ & $\begin{array}{l}\mathrm{r} 452 \\
\mathrm{I} 006\end{array}$ & $\begin{array}{l}713,1225 \\
700,956\end{array}$ \\
\hline SR I I 58 & $\begin{array}{l}37 \frac{2}{2} \\
33^{\prime}\end{array}$ & $2 \mathrm{I}^{\prime}$ & I5. v. II & I $234-1478$ & $\begin{array}{l}700,950 \\
731,1234\end{array}$ \\
\hline SR I 228 & $36^{\prime}$ & $19^{\prime}$ & I0. viii. II & II 67 & 823,1097 \\
\hline SR I379 & $3 I^{\prime}$ & $16^{\prime}$ & II. v. I2 & 977 & $73 \mathrm{I}, 9 \mathrm{I} 4$ \\
\hline$S_{1}{ }_{1439}$ & $27^{\prime}$ & $20^{\prime}$ & I4. viii. I2 & $95 \mathrm{I}$ & 640,914 \\
\hline SR I6I3 & $29^{\prime}$ & $22^{\prime}$ & I5. v. I3 & 960 & 640,914 \\
\hline SR I677 & $35^{\prime}$ & I8' & I4. viii. I3 & I072 & 731,987 \\
\hline SR I 824 & $33^{\prime}$ & $23^{\prime}$ & I4. v. I4 & I379 & 914,1280 \\
\hline $\mathrm{SR}_{2158}$ & $34^{\prime}$ & $17^{\prime}$ & I4. v. 25 & 1037 & 1000 \\
\hline SR 2I 73 & $34^{\prime}$ & I $7^{\prime}$ & 24. xi. 25 & II 52 & I097 \\
\hline SR 222I & $34^{\prime}$ & $17^{\prime}$ & I7. viii. 26 & 797 & 768 \\
\hline SR 2244 & $34^{\prime}$ & $17^{\prime}$ & I9. ii. 27 & 906 & 860 \\
\hline SR 2270 & $34^{\prime}$ & $17^{\prime}$ & 10. v. 27 & 1004 & 966 \\
\hline SR 2290 & $34^{\prime}$ & $17^{\prime}$ & 27. xi. 27 & 1049 & 1024 \\
\hline SR23II & $34^{\prime}$ & $16^{\prime}$ & I4. iv. 28 & 906 & 878 \\
\hline SR 2353 & $34^{\prime}$ & $16^{\prime}$ & 21. ii. 29 & IOI6 & 986 \\
\hline $\mathrm{SR}_{2382}$ & $35^{\prime}$ & $12^{\prime}$ & 3. vi. 29 & 843 & 800 \\
\hline $\mathrm{SR}_{2404}$ & $36^{\prime}$ & $15^{\prime}$ & 12. viii. 29 & 873 & 840 \\
\hline SR 2420 & $34^{\prime}$ & $16^{\prime}$ & I. xii. 29 & 1027 & 750,978 \\
\hline SR 2487 & $37^{\prime}$ & I9' & 26. v. 3I & 856 & 695 \\
\hline SR 2509 & $34^{\prime}$ & I $4^{\prime}$ & I7. viii. 3 I & 767 & 750 \\
\hline SR 2533 & $38^{\prime}$ & $14^{\prime}$ & 3. ii. 32 & 769 & 720 \\
\hline Challenger I & $25^{\prime}$ & $15^{\prime}$ & 26. vi. 32 & 815 & 750,795 \\
\hline SR 2585 & $4 \mathrm{I}^{\prime}$ & $17^{\prime}$ & 8. viii. 32 & 989 & $700,800,950$ \\
\hline $\mathrm{SR}_{26} 64^{\circ}$ & $35^{\prime}$ & $16^{\prime}$ & I7. v. 33 & I016 & $700,800,969$ \\
\hline SR 2664 & $35^{\prime}$ & $16^{\prime}$ & 8. viii. 33 & IO73 & $700,800,1042$ \\
\hline SR 2725 & $34^{\prime}$ & $15^{\prime}$ & I2. vi. 34 & 847 & 700,800 \\
\hline WS962 & $34^{\prime}$ & Io' & I8. i. 50 & 922 & 780,880 \\
\hline WS963 & $34^{\prime}$ & $30^{\prime}$ & I9. i. 50 & I3II & $\begin{array}{l}660,750,800,850, \\
930,970, \text { 1010, 1065, } \\
\text { I1 } 70, \text { I } 270\end{array}$ \\
\hline
\end{tabular}

(Table XIV). The results for the years I9I0-I4 have been read from Mr D. J. Matthews's record cards, now in the writer's possession, and those for later years have been extracted from the Bulletins Atlantiques and Bulletins Hydrographiques published by the International Council for the Exploration of the 
Sea. The series has been supplemented by one by H.M.S. Challenger in 1932 (Cons. Int., Bull. Hydrogr. for I932) and by interpolated results from the two outermost William Scoresby stations in 1950 (Cons. Int., Bull. Hydrogr. for 1950). Depths observed ranged from 767 to $1478 \mathrm{~m}$.

Mean temperatures, salinities and densities have been evaluated (Table XV), by interpolation where necessary, for standard depths at intervals of $100 \mathrm{~m}$. from 100 to $1000 \mathrm{~m}$. Down to $600 \mathrm{~m}$., the sampling intervals were small enough to make interpolation safe except on I7 August I93I. Below 60I m. in many years only one depth was sampled so that interpolation may have caused error. The curves have been slightly adjusted so that salinity, temperature and density are consistent. Moreover, on some occasions, bottom was found above $800 \mathrm{~m}$. Although the assessment of mean values at $800-1000 \mathrm{~m}$. must be subject to greater error than in the upper waters, the error of the temperature mean appears not to exceed $\pm 0.02^{\circ} \mathrm{C}$. Standard deviations of the means are also included in Table XV.

Table XV. Mean Temperatures, Salinities and Densities at Standard

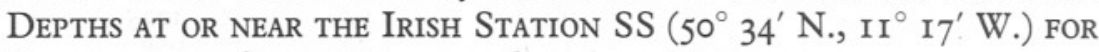
Twenty-nine Occasions, with Standard Deviations

$\begin{array}{cccc}\begin{array}{c}\text { Depth } \\ \text { (m.) }\end{array} & \begin{array}{c}\text { Temperature } \\ \left({ }^{\circ} \mathrm{C} .\right)\end{array} & \begin{array}{c}\text { Salinity } \\ (\%)\end{array} & \begin{array}{c}\text { Density } \\ \left(\sigma_{t}\right)\end{array} \\ \text { 100 } & \text { II.02 } \pm 0.43 & 35.52 \pm 0.04_{9} & 27 \cdot 19 \pm 0.08_{2} \\ 200 & 10.74 \pm 0.26 & 35.52 \pm 0.06_{2} & 27.24 \pm 0.05_{0} \\ 300 & 10.62 \pm 0.22 & 35.52 \pm 0.05_{1} & 27.26 \pm 0.03_{6} \\ 400 & 10.50 \pm 0.19 & 35.51 \pm 0.06_{0} & 27.28 \pm 0.03_{5} \\ 500 & 10.31 \pm 0.14 & 35.50 \pm 0.04_{4} & 27.30 \pm 0.03_{8} \\ 600 & 10.09 \pm 0.14 & 35.50 \pm 0.05_{5} & 27.34 \pm 0.04_{7} \\ 700 & 9.83 \pm 0.20 & 35.51 \pm 0.045 & 27.40 \pm 0.044_{5} \\ 800 & 9.54 \pm 0.27 & 35.54 \pm 0.04_{0} & 27.47 \pm 0.04_{8} \\ 900 & 9.28 \pm 0.31 & 35.55 \pm 0.04_{5} & 27.52 \pm 0.05_{0} \\ 1000 & 8.92 \pm 0.43 & 35.54 \pm 0.04 & 27.57 \pm 0.06_{2}\end{array}$

Vertical mixing would seem to proceed at all depths on a considerable scale (Cooper, I952a, fig. 2). Although the water at $1000 \mathrm{~m}$. is commonly of very different origin from that at $100 \mathrm{~m}$., the uniformity in salinity from top to bottom is notable. The result illustrates the futility of treating all high-salinity waters in the Celtic Sea as carrying uniform chemical and biological properties.

The stratum of most constant temperature lies between 500 and $600 \mathrm{~m}$., that of most constant density between 300 and $500 \mathrm{~m}$. The deepest water at I000 $\mathrm{m}$. shows a greater range of temperature and of density than any other stratum below $150 \mathrm{~m}$. A similar result has been found in the open Atlantic at $44^{\circ} 36^{\prime}$ N., $20^{\circ} 00^{\prime}$ W. (Fig. 2). The relatively large standard deviation of the density at $1000 \mathrm{~m}$. must mean that the currents there are of the same order of magnitude as those at $100 \mathrm{~m}$. These deep currents will affect all attempts at dynamic computation of surface currents. The reference level of assumed no motion in the Eastern North Atlantic needs to be taken very deep. Moreover, the strong slope of deep geopotential topographies should 
have a very pronounced effect, possibly a controlling effect, on surface currents. It may explain, in part, the great difficulty in assessing surface currents in the Atlantic near the continental slope of the Celtic Sea.

\section{Variations in the Gulf of Gibraltar and 'Rockall Cascade' Waters at Station SS}

The strength of the tongue of Gulf of Gibraltar water varies much from time to time. The largest changes between successive observations are given in Table XVI. Between May and August I9I I water entered between 700 and at least $820 \mathrm{~m}$. depth which was both much warmer and more saline; it was undoubtedly Gulf of Gibraltar water. Between the same months in I933, the converse happened, the Gulf of Gibraltar water was pushed out by colder and less saline water. This is the more usual occurrence.

Dates $\quad \overbrace{800 \mathrm{~m} . \quad{ }_{900 \mathrm{~m} . \quad \text { Increase in salinity }(\%)}^{\text {TABLE XVI }} \text { 1000 m. }}^{\text {Increase in temperature }\left({ }^{\circ} \mathrm{C} .\right)}$

(a) Salinity and temperature increased or decreased together

$\begin{array}{lllllll}\text { I5. v.-IO. viii. II } & +0.09 & - & - & +0.63 & +0.69 & +0.70 \\ \text { I7. v. }-8 \text {. viii. } 33 & -0.07 & -0.09 & -0.09 & -0.30 & -0.40 & -0.52\end{array}$

(b) Salinity and temperature moved in opposite phase

27. xi. 27 -I4. iv. $28+0.06 \quad+0.08 \quad-\quad-0.62 \quad-0.78$ -

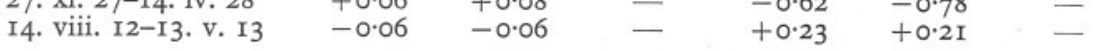

During the winter of 1927-8 between November and April at about $880 \mathrm{~m}$. water about $0.08 \%$ more saline but half a degree colder came in; yet in the winter of $\mathrm{I}_{912-\mathrm{I} 3}$ at about $900 \mathrm{~m}$. water $0.06 \%$ less saline and $0.20^{\circ} \mathrm{C}$. warmer entered. These last events cannot be correlated with changes in the Gulf of Gibraltar component. A detailed study of variations in salinity on the lines of the analysis of temperature to follow has not revealed any rhythmic change in the distribution of salinity.

There are striking variations in temperature at 800-1000 m. depth, but owing to the heterogeneous nature of the data they are not presentable in a simple form. They may be most surely shown by the following procedure.

(i) The temperatures at $100 \mathrm{~m}$. intervals from 100 to $1000 \mathrm{~m}$. were tabulated, when necessary interpolating graphically and checking that temperatures, salinity and density are mutually consistent. (ii) The mean temperature at each standard depth for all observations at station SS was then evaluated. (iii) At 800 , at 900 and at $1000 \mathrm{~m}$., the deviations of each observed or interpolated temperature from the mean for the depth was worked out. (iv) The deviations at $800 \mathrm{~m}$. and, when available, at 900 and $1000 \mathrm{~m}$., were then averaged to give the best assessment possible of the mean deviation of the temperature of the $800-1000 \mathrm{~m}$. stratum from its overall average. (v) The changes in these mean deviations as measured on cruises a quarter or half year apart were then computed (Table XVII). 
The result is no more than a measure of the changes in the temperature of the $800-1000 \mathrm{~m}$. stratum considered as a whole. The summer of I9I I was exceptional (p. 495), and all results involving it are enclosed in square brackets and omitted from the means.

There is a seasonal change in temperature with a range of about $0.5^{\circ} \mathrm{C}$. The water at $800-1000 \mathrm{~m}$. has been warmest in November and coldest in August. Nearly all the warming up occurs between August and November.

Table XVII. Changes in the Mean Temperature of the 800-IO00 M. Stratum at Station SS BetWeEn CRUises a QUARTER AND A HALF-YeaR APART

\begin{tabular}{|c|c|c|c|c|c|c|c|}
\hline \multicolumn{8}{|c|}{ Quarterly intervals } \\
\hline \multirow[b]{2}{*}{ Feb.-May } & I9II & I927 & $1929^{\star}$ & & & & Mean \\
\hline & $\begin{array}{c}{[-0.48]} \\
\text { I } 91 \mathrm{I}\end{array}$ & $\begin{array}{l}-0.60 \\
1912\end{array}$ & $\begin{array}{l}-0.17 \\
1913\end{array}$ & 1929 & $1932 \dagger$ & 1933 & $-0 \cdot 39$ \\
\hline May-Aug. & $\begin{array}{c}{[+0.68]} \\
1929\end{array}$ & -0.14 & -0.04 & -0.04 & -0.22 & -0.40 & $-0 \cdot 17$ \\
\hline Aug.-Nov. & \multicolumn{4}{|c|}{+0.28} & & & $+0 \cdot 28$ \\
\hline Nov.-Feb. & \multicolumn{4}{|c|}{ No pairs of observations available } & & & - \\
\hline \multicolumn{8}{|c|}{ Half-yearly intervals } \\
\hline & \multicolumn{3}{|l|}{ I927/8 } & \multicolumn{4}{|l|}{ Mean } \\
\hline Nov.-Apr. & \multicolumn{3}{|l|}{$\begin{array}{l}-0.78 \\
\text { IgII }\end{array}$} & \multicolumn{4}{|l|}{-0.78} \\
\hline Feb.-Aug. & $\begin{array}{c}{[+0 \cdot 20]} \\
1925\end{array}$ & $\begin{array}{l}-0.25 \\
1927\end{array}$ & I929 & \multicolumn{4}{|l|}{-0.25} \\
\hline May-Nov. & $\begin{array}{l}+0 \cdot 01 \\
+1910 / 11\end{array}$ & $\begin{array}{c}+\mathrm{I} \cdot 16 \\
1926 / 27\end{array}$ & +0.24 & \multicolumn{4}{|l|}{$+0 \cdot 47$} \\
\hline Aug.-Feb. & +0.12 & +0.44 & & \multicolumn{4}{|l|}{$+0 \cdot 28$} \\
\hline \multirow[t]{2}{*}{ Aug.-May } & $\begin{array}{l}\text { I910/II } 19 \\
{[-0.36][+}\end{array}$ & $\begin{array}{ll}1 / 12 & 1912 / 13 \\
0.23] & +0.22\end{array}$ & $\begin{array}{cc}3 & 1913 / 144 \\
+ & +0.08\end{array}$ & $\begin{array}{l}1926 / 27 \\
-0.16 .\end{array}$ & $\begin{array}{l}193 \mathrm{I} / 32 \ddagger \mathrm{I} \\
+0.42\end{array}$ & $\begin{array}{l}1932 / 331933 / 34 \\
+0.51+0.31\end{array}$ & $\begin{array}{r}\text { Mean } \\
+0.23\end{array}$ \\
\hline & \multicolumn{6}{|c|}{$\begin{array}{l}\star 21 \text { Feb.-3 June. } \\
\ddagger \text { I } 7 \text { Aug. I } 93 \text { I-26 June } 1932 \text { June (Challenger Station I) }-8 \text { Aug. }\end{array}$} & \\
\hline
\end{tabular}

Analysis of the observations by other methods has shown that the extent of the cooling between May and August has been somewhat exaggerated; most of the cooling occurs between February and May, the season of cascading of shelf water (Cooper \& Vaux, I949), which undoubtedly may affect the water down to $1000 \mathrm{~m}$. depth.

Water in the Celtic Sea never becomes heavy enough to sink so far and it is doubtful if Porcupine Bank water could either. Water of sufficient density could only be found at the surface still farther north. None the less, north of $60^{\circ} \mathrm{N}$. and also over the Rosemary Knoll ${ }^{1}$ the salinity is almost always too low. Over the extensive Rockall Table Mount ${ }^{1}$ water of appropriate density,

${ }_{1}$ Name in accordance with the recommendations of the British National Subcommittee on Nomenclature of Ocean Bottom Features. 
salinity and temperature often occurs. I am much indebted to Lt.-Cmdr. J. R. Lumby, R.N., for providing me from his card index with a complete set of surface hydrographical observations for the months of January to April over the Rockall Table Mount between $56^{\circ} 30^{\prime}$ and $58^{\circ} \mathrm{I} 5^{\prime} \mathrm{N}$. lat. and $13^{\circ}$ and $15^{\circ} \mathrm{W}$. long. From them the mean surface density there has been computed for each month (Table XVIII); 2 I \% of these observations show a surface salinity of $35.45 \%$ or more. During passage south the salinity of Rockall cascade water would be expected to increase somewhat, due to lateral mixing.

Considering only the statics of the system, heavy saline water formed in winter over the Rockall Table Mount could account for the fairly regular seasonal fluctuation of the water at $800-1000 \mathrm{~m}$. depth at station SS (cf. also Nansen, I9I2). However, the dynamics of a north-south section across the North Atlantic Drift requires a density distribution in this sense with heavy surface water on the left or north and light water on the right or south. Even

\section{TABLE XVIII}

\begin{tabular}{|c|c|c|c|}
\hline \multirow[b]{2}{*}{ Month } & \multicolumn{2}{|c|}{$\begin{array}{l}\text { Mean density of surface water } \\
\text { over Rockall Table Mount }\end{array}$} & \multirow{2}{*}{$\begin{array}{c}\text { Depth at station } \\
\text { SS at which } \\
\text { such a mean } \\
\text { density is } \\
\text { recorded; from } \\
\text { Table XV } \\
\text { (m.) }\end{array}$} \\
\hline & $\begin{array}{c}\text { No. of } \\
\text { observations }\end{array}$ & $\sigma_{t}$ & \\
\hline January & I2 & $27 \cdot 46$ & 790 \\
\hline February & I2 & 27.57 & 1000 \\
\hline March & 26 & 27.50 & 860 \\
\hline April & 33 & $27 \cdot 44$ & 750 \\
\hline
\end{tabular}

so, if a cold winter produces a sudden increase in the density of the water overlying the shallow Rockall Table Mount, then the steady state of the drift would be upset. Either its speed towards the east or north-east must increase to carry a greater volume of saline water into the northern North Sea, or the heavy water must cascade towards the south, undercutting the North Atlantic Drift. Both may probably happen to different degrees in different years. Tait (I95I) has remarked that in the northern North Sea the predominance of oceanic influence is in most years at a maximum in spring and early summer and at a minimum in autumn and winter, and that these seasonal variations are subject to annual fluctuations in their magnitude and incidence. This, qualitatively, is the effect which increase in density during cold weather in February and March over the shallow Rockall Table Mount and the neighbouring banks or knolls would produce. The evidence from station SS and from Armauer Hansen station I9I4/6 is that this heavy water may also cascade and then flow southwards along the continental slope in some winters for over 500 miles.

Although incursions of Gulf of Gibraltar water will lead to warming up at any season, it seems clear that only in the summer of I9I I was it dominant over the seasonal oscillation due to the 'Rockall cascade' current. The greatest 
changes in density occurred: (i) August I9Io-February-May I9II when the overall increase much exceeded O.IO $\sigma_{t}$-unit; (ii) February-May I927 when the density increased by $0.09 \sigma_{t}$-unit due entirely to a fall in temperature of $0.5^{\circ} \mathrm{C}$. On the latter occasion the salinity scarcely changed. The phenomenon was probably associated with cascading from the continental shelf of water having salinity $35.55 \%$, temperature $8 \cdot 2-9 \cdot 2^{\circ} \mathrm{C}$. and density $27 \cdot 54-27 \cdot 68$ $\sigma_{t}$-unit. Such water cannot have originated in the Celtic Sea and can only have come from farther north. On I February 1927 water having salinity $35.48 \%$, temperature $8.2^{\circ}$ C. and $\sigma_{t} 27.65$ was reported (Cons. Int., Bull. Hydrogr. for 1927) on the Danish line of surface stations between Copenhagen and New York at $59^{\circ} \mathrm{Oz}^{\prime} \mathrm{N}$., $\mathrm{II}^{\circ} \mathrm{Oo} \mathrm{o}^{\prime} \mathrm{W}$. It is likely, therefore, that the chilled water at station SS ( $50^{\circ} 34^{\prime}$ N., II ${ }^{\circ} \mathrm{I}^{\prime}$ W.) had been formed by cooling and

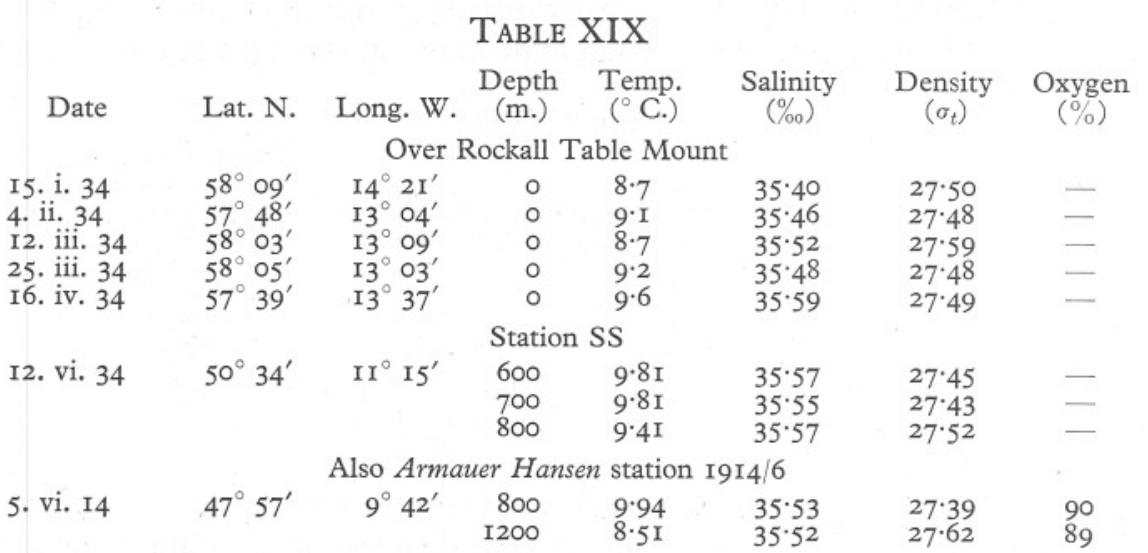

cascading of the water in the North Atlantic Drift passing over the Rockall Table Mount. North Atlantic Central water carried towards Rockall is likely, whilst on passage around and over the Table Mount, to be modified by capsizing against the island slope during high winds. If the Rockall Table Mount was indeed its origin it had subsequently moved south at the rate of about 5 miles a day. The year 1934 showed the effect particularly clearly (Table XIX).

There is little doubt that at station SS in June I934 there was a large northern component at $600-800 \mathrm{~m}$. Similarly, the highly oxygenated waters reported from the Armauer Hansen expedition in I9I4 by Gaarder (1927) at station 6 at 800 and $1200 \mathrm{~m}$., sandwiching oxygen-depleted water ( 72 and $77.5 \%$ saturated) at 900 and $1000 \mathrm{~m}$., would seem certainly to have been of northern surface origin.

Ability to cascade from north to south depends not on any absolute but on relative values of density. Thus ten observations of computed surface density by Ocean Weather ships over the Rockall Table Mount in February-April I950 revealed a somewhat low mean density of 27.4I $\sigma_{t}$. Nevertheless, the 
waters at station SS in the 'South Porcupine submarine indentation' in January I950, also light relative to earlier years, could have subsequently accommodated such water down to $900 \mathrm{~m}$. Considerable north-south cascading was possible.

The dynamics of such a descending mid-water current of cascade origin, hugging the continental slope on its left, needs attention. It is clear that immediately west of the British Isles in spring and summer geopotential topographies (for definition see Sverdrup et al. (I942, p. 404)), suggesting surface currents to the north and north-east, need to be interpreted with especial care. A mid-water descending current in the opposite direction and of considerable magnitude is always likely. It is now realized that such a current system would contribute to the difficulty experienced in interpreting the Dana section across it in June I938. This has not been re-examined.

In March and April and even perhaps in May, severe gales from between south-west and north-west would, by causing capsizing, destroy this descending mid-water cascade current during its passage along the western fringe of the British Isles. Northern cascade water would not then reach south-west Ireland in an identifiable form.

The winter and spring of 1927 was a period of strong cascading (Cooper \& Vaux, 1949). The low inorganic phosphate found that year by Atkins at $860 \mathrm{~m}$. at station SS (Table X, and compare Cooper I952a, fig. 2) suggests that by mid-February little water from the south was present. During the spring cascading from the Celtic Sea continued strongly, followed during the summer and autumn by a very strong recession of cascade water. By November the water at $1000 \mathrm{~m}$. had warmed up by $1_{4}{ }^{\circ} \mathrm{C}$. and had become lighter than any water recorded there between I9I0 and I934. By April I928 this warm light water had again been displaced by a dense, saline water of intermediate temperature $\left(35.6 \mathrm{I} \%, 9.0-9.4{ }^{\circ} \mathrm{C}\right.$. and $\left.\sigma_{t} 27.58-27.6 \mathrm{I}\right)$, this water having a strong Gulf of Gibraltar component. It is clear that during I927, as a whole, water movements around $800-1000 \mathrm{~m}$. were on a scale greater than in any other year for which we have sufficient records (Table XIV). Quite apart from vertical exchanges, the resulting alterations of deep geopotential topographies must have had a very considerable effect on those at the surface. Unusual surface currents above the continental slope of the western Celtic Sea were likely in that year.

\section{Seasonal Variations at Station SS in the 200-400 m. Water Stratum}

The seasonal variations for the $200-400 \mathrm{~m}$. stratum have been worked out in the same way as those at $800-1000 \mathrm{~m}$. (Table XX). The scarcity of observations in November has made difficult the distribution of changes as between autumn and early winter. Most surprising was that the changes in temperature from season to season at $200-400 \mathrm{~m}$. were on an average less than one-fifth of those at 800-1000 $\mathrm{m}$. The remaining conclusions are tabulated in Table XXI. 
Table XX. Changes in the Mean Salinity and Temperature of the 200-400 M. Stratum at Station SS between Cruises a Quarter OR A HALF-YEAR APART

\section{Salinity}

Quarterly intervals

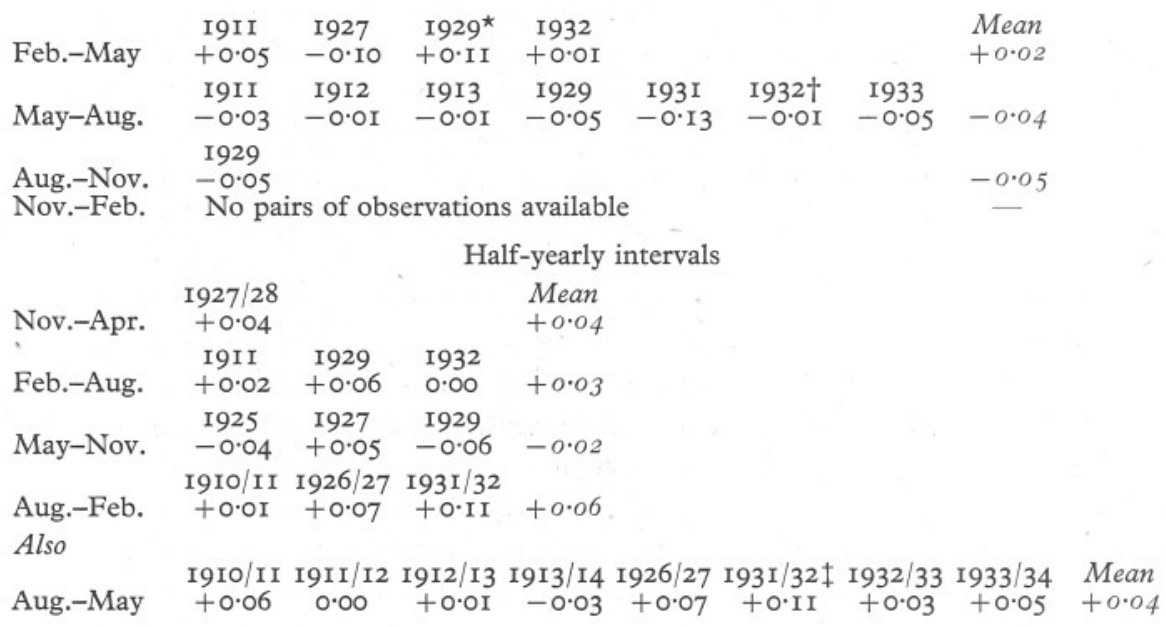

\section{Temperature}

Quarterly intervals

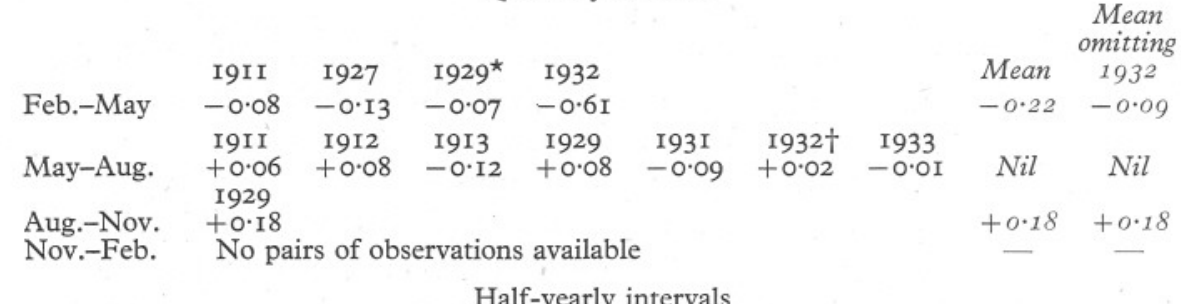

Half-yearly intervals

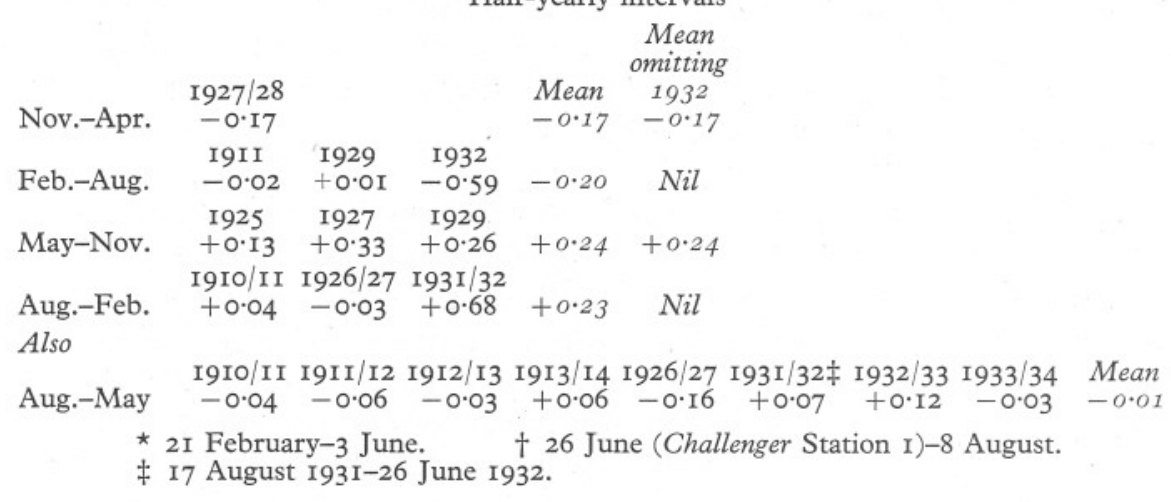


Table XXI. Seasonal Variations at Station SS in the 200-400 M. WATER STRATUM

\begin{tabular}{cc} 
Feb.-May & \multicolumn{1}{c}{$\begin{array}{c}\text { Temperature } \\
\text { Average decrease of at least } \\
0.09^{\circ} \mathrm{C} \text {. Very marked de- } \\
\text { crease }\left(0.6^{\circ}\right) \text { in } 1932\end{array}$} \\
May-Aug. & Little change \\
May-Nov. & $\begin{array}{l}\text { Average increase of } 0.2^{\circ}, \\
\text { mostly between August } \\
\text { and November }\end{array}$ \\
Aug.-Feb. & $\begin{array}{l}\text { Net slight overall tendency } \\
\text { to increase; very strong } \\
\text { warming }\left(0.7^{\circ}\right) \text { in autumn } \\
\text { of } 193 \mathrm{I}-32\end{array}$
\end{tabular}

\author{
Salinity \\ Variable. Average increase of merely \\ $0.02 \%$. In 1927 , a year of strong \\ cascading of shelf water, there was a \\ decrease of $0.10 \%$. For I930, pro- \\ bably a year of strong cascading, no \\ observations are available \\ Decrease in every year, average decrease \\ $0.04 \pm$ (s.D.) $0.04 \%$. (The statistical \\ distribution is not 'normal'.) \\ Little regular change
}

Average increase of about $0.06 \%$

N.B. Owing to the nature of the distribution of the observations in time, the positive and negative assessments cannot be expected exactly to cancel.

\section{Density}

Feb.-May Average increase of about $0.06 \sigma_{t}$-unit

May-Aug. Average decrease of about $0.03 \sigma_{t}$-unit

Aug.-Nov. Average decrease of about $0.03 \sigma_{t}$-unit

Nov.-Feb. Little change

\section{Recent Warming up of the Upper layers at Station SS}

For the twenty-nine sets of observations at and near station SS the departures from the mean temperature of the $200-400 \mathrm{~m}$. stratum are presented in Table XXII. Positive departures are stressed by italic type. In the years I9IO-I4 and again from May I925 to Máy 1927 the water was consistently colder than the average by $0.2^{\circ} \mathrm{C}$. No records are available for the exceptionally warm autumn of I92I (cf. Harvey, I923).

During the summer of 1927 markedly warmer water arrived and remained with minor recessions until the end of the Irish observations in 1934 .

When the position was next examined on I8-I9 January I950 by R.R.S. William Scoresby, the stratum was found to be $0.7^{\circ} \mathrm{C}$. warmer as compared with I9I0-I4 and I925 (cf. Helland-Hansen, I949).

Smed (1949a,b, 1950) has found that there has been a warming up since about 1932 of the surface waters in the north-eastern North Atlantic in his areas $\mathrm{I}, \mathrm{H}$ and $\mathrm{L}$ (between 55 and $67^{\circ} \mathrm{N}$. lat. and between $\mathrm{Io}$ and $20^{\circ} \mathrm{W}$. long.), in area $\mathrm{J}$ (between 60 and $64^{\circ} \mathrm{N}$. and between 0 and $10^{\circ} \mathrm{W}$.), and in area $\mathrm{K}$ (between 58 and $60^{\circ} \mathrm{N}$. and between 3 and $10^{\circ} \mathrm{W}$.). It would seem from his reports that the marked warming up first appeared in the north about 1927 and that it is spreading towards the south and south-west. His findings seem to be compatible not with an increased transport of heat by the North Atlantic Drift but rather with reduced abstraction in the north of the heat transported. If this has been so, winter cascading from the more northern 
shallow areas, such as the Rockall Table Mount, will have been affected and the rate of formation of the North Atlantic Deep water still farther north may have been reduced (see also Cooper, $1952 b$ ).

On the other side of the Atlantic, Lauzier (I950) has reported that from April to October 1949 the surface temperatures at St Andrews (mouth of the Bay of Fundy) and at Halifax (Nova Scotia) Lightvessel were much higher than usual, indeed the highest ever recorded.

TAble XXII. Warming up of Upper Waters (200-400 M.) at Station SS BETWEeN I9IO AND I950, SHOWN By DePartures From MEAN TEMPERATURES

\begin{tabular}{|c|c|c|c|c|c|}
\hline & & & & & \\
\hline Year & February & May & August & November & Period average \\
\hline $\begin{array}{l}\text { I9IO } \\
\text { I9II }\end{array}$ & $-\overline{0} \cdot 6$ & - & -0.20 & - & \\
\hline $\begin{array}{l}\text { I9II } \\
\text { I9I2 }\end{array}$ & -0.16 & -0.24 & -0.18 & - & \\
\hline $\begin{array}{l}1912 \\
1013\end{array}$ & - & -0.24 & -0.16 & - & \\
\hline $\begin{array}{l}1913 \\
\text { I914 }\end{array}$ & - & -0.19 & $-0.3 I$ & - & \\
\hline $\begin{array}{c}\text { I9I4 } \\
\text { Mean } 19 \text { IO-I4 }\end{array}$ & - & -0.25 & - & - & \\
\hline Mean $1910-14$ & -0.16 & -0.23 & -0.21 & - & -0.18 \\
\hline $\begin{array}{l}\text { I924 } \\
\text { I926 }\end{array}$ & 二 & -0.30 & $\overline{0.00}$ & -0.17 & \\
\hline 1927 & -0.03 & -0.16 & - & 二 & \\
\hline $\begin{array}{l}\text { Mean I925- } \\
\text { May I927 }\end{array}$ & - & - & - & - & -0.13 \\
\hline $\begin{array}{l}1927 \\
1928\end{array}$ & - & - & - & $+0 \cdot 17$ & \\
\hline $\begin{array}{l}1920 \\
1929\end{array}$ & $+\overline{0.20}$ & $\begin{array}{r}0.00 \\
+0.13\end{array}$ & $+\overline{0 \cdot 11}$ & $+\overline{0.30}$ & \\
\hline 1930 & - & - & - & - & \\
\hline I93I & - & +0.02 & -0.07 & - & \\
\hline 1932 & +0.48 & +0.04 & +0.02 & - & \\
\hline 1933 & - & $+0 \cdot 14$ & +0.13 & 二 & \\
\hline $\begin{array}{l}\text { I934 } \\
\text { Nevemb }\end{array}$ & - & +0.10 & - & - & \\
\hline $\begin{array}{r}\text { Mean November } \\
\text { I927-May I } 934\end{array}$ & $\begin{array}{r}r+0 \cdot 34 \\
4\end{array}$ & +0.07 & +0.08 & +0.28 & +0.19 \\
\hline I950 & $\begin{array}{c}+0.5^{2} \\
\text { (January) }\end{array}$ & - & - & - & $(+0.52)$ \\
\hline
\end{tabular}

These events reflect the general warming up of the North Atlantic. One result is that the temperature-salinity relationships, epitomized in equations (I) and (2) (pp. 467 and 479) and drawn in Figs. 9 and I5, now refer to an age that is past. They need to be re-determined from fresh observations.

\section{DisCUSSION}

The purpose of this paper has been twofold: first, by achieving a better understanding of the exchanges of water with the Atlantic, to assist the preparation of papers to follow on the hydrography of the Celtic Sea and English Channel; and, secondly, to enable future investigations over the continental slope to be better directed to the solution of defined problems. It is a contribution to 'experimental oceanography'. 
There is clearly a need for repeated observations at fixed points in deep water off the slope to keep track of the very considerable fluctuations which occur at all depths above $1500 \mathrm{~m}$.

The theory of 'capsizing' water masses over the continental slope seems plausible. If capsizing can be shown to be dynamically sound and can be demonstrated by clear-cut observations, it provides a mechanism of great power for enriching the surface waters of the sea with deep nutrients.

It seems probable that, in general terms, winds of a given strength will prove very much more effective in producing extensive capsizing if preceding conditions have been optimal. Many variations of circumstances can be visualized. Thus, if strong winds have blown from between north and east for some time, as they did in February 1947, some degree of upwelling by the classical mechanism would occur. If then the wind veered quickly to the south, reaching gale force and producing severe capsizing while nutrient-rich water stood banked high against the slope, there would arise very favourable conditions for surface enrichment of a kind which would occur only a few times in a century.

It is necessary also to follow the conflict at $800-1000 \mathrm{~m}$. depth between Gulf of Gibraltar water and cascade water from the north and to learn more of their properties. The Irish station SS, already worked twenty-seven times, is an obvious choice. It lies on the edge of the 'South Porcupine submarine indentation' which may act like an electrical choke, ironing out short-period fluctuations appearing in the water outside the indentation. On occasion, as on I4 May I925 and I9 February I927 (Cooper, I952 $a$, fig. 2), the compression of the temperature-salinity diagram suggests that vertical exchanges may become very large (cf. Atkins's determination (Table X) of inorganic phosphate at $860 \mathrm{~m}$. at station SS on I9 February 1927, which was surprisingly low for such a depth). For purposes of comparison the $T-S$ relationship found immediately south of the Celtic Sea at Armauer Hansen station I9I4/6 (Figs. 8 and 9) and at Armauer Hansen station I9I4/I5 in the open Atlantic are included.

In such a submarine indentation, internal waves probably resonate strongly, causing great turbulence and vertical mixing and, by so doing, destroying themselves. Combined studies of cascading, capsizing, internal waves and resonance in this indentation will be necessary. Capsizing against either wall of the indentation should itself induce deep internal waves which would be expected to resonate strongly.

An additional Irish station has been worked three times, at $50^{\circ} \mathrm{oO}^{\prime} \mathrm{N}$., $\mathrm{I}^{\circ} \mathrm{O}^{\prime} \mathrm{W}$. The observations there have been consistent with those at station SS. It is in a strategic position north of the 'Sole submarine promontory' which seems sometimes to be a water parting.

Cascaded shelf-waters play an important part. It will be necessary to substantiate that the deeper cascade waters, do, in fact, come from the north, 
probably from the Rockall Table Mount. A solution will require (i) a knowledge of the frequency of occurrence over the Rockall Table Mount, and over the other elevations of the sea-bed towards the east and north-east, of suitable water sufficiently heavy and in sufficient amount to cascade to the south and to undercut the main North Atlantic Drift; (ii) establishment of a descending current in late spring and summer along the continental slope west of the British Isles; (iii) determination of oxygen contents throughout the whole area, since waters from the Gulf of Gibraltar and the Atlantic to the southwest at around $1000 \mathrm{~m}$. would be expected to have an oxygen content between 65 and $70 \%$ saturated, whereas recently cascaded water should exceed $85 \%$ saturated; (iv) a study of silicate distribution, which is likely to help; (v) a satisfactory account of the dynamics of a mid-water current gliding downhill towards the south with the continental slope on its left.

Cascading and capsizing are very different processes which may produce in our waters markedly similar distributions of salinity, temperature and oxygen. Often they may combine to give a large mass of water of composite origin. They should be distinguishable and the degree of admixture of the two waters or processes should be assessable in terms of the content of nutrients, especially silicate. Capsized water should be the richer.

Fraser (I950) states that the Scottish fisheries research vessels have found biological indications of two water masses approaching Faeroe from the southwest. One, the 'Lusitanian' stream, has travelled via the west coasts of Ireland and Scotland and will have been influenced by any vertical exchanges over and along the continental slope; the other, the Atlantic stream, travels farther west. The two streams, at least in the middle and late summer, are said to be very distinct but mix along the line of meeting. Such biological distinctions probably indicate chemical differences in the waters which may persist awhile. It would be desirable to know which of these waters bathes the Rockall Table Mount and other areas of formation in winter of cascaded water.

May one ask whether the 'Lusitanian' water may be identifiable with a 'capsized and cascaded water' similar to that at stations 6-8 of Fig. II? Such water should exist all along the west European continental slope and for 75-I50 miles to seaward. The 'Atlantic' water of the Scottish workers would then be identifiable with the 'North Atlantic Central' water of stations 9-I5 and its winter-mixed surface skin.

The North Atlantic Drift carries warm-water plankton organisms ever northwards and eastwards into colder regions unsuitable for their reproduction. Any mechanism for returning part of the stock to the south should assist its survival. If therefore there are any organisms, not only animals but perhaps diatoms as resting spores, which can avail themselves of the deeper return current of cascade origin, their survival should be favoured. Diatom resting spores could only profit if they complete their travels by being brought 
up to illuminated surface waters by some form of upwelling such as capsizing. Cascade water, formed as it is in winter, will start by being reasonably rich in nutrients and will become further enriched by lateral exchange or capsizing with richer deep North Atlantic Central or Gulf of Gibraltar water. Resting spores brought up in such water to illuminated levels would be able immediately to initiate rapid cell division. In their new home they would be considered to be more northern species. If this cyclical process can be firmly established as occurring it provides not only the nutrients required for growth but the seeds of life itself.

The mid-water cascade current will take time on its journey south. It will sink in the north mostly in February and March and will not reach its southern limit until late in the spring. Species of plants and animals which may be said to be characteristic of the waters around $58-60^{\circ} \mathrm{N}$., I2-1 $5^{\circ} \mathrm{W}$., and would there start their seasonal reproductive cycle in, say, March, would not reach more southern waters until later in the spring.

Again, since the intensity of cascading will be related to air and sea temperatures in the more northern area, after warm 'northern' winters the 'seed' stock of northern species of phyto- and zooplankton abreast of the Celtic Sea should be poor, while after cold 'northern' winters it should be relatively rich. It should therefore be worth while to seek a correlation between abundance of 'more northern' species in May and June between 48 and $50^{\circ} \mathrm{N}$. with air and sea temperatures in February and March between 58 and $60^{\circ} \mathrm{N}$. Intensity of cascading should not be related so much to deviations of temperature from all-time means but to deviations from short-period average conditions. Therefore, such a correlation should be sought not in terms of all-time but in terms of immediately preceding decade means.

South of the Celtic Sea only one position has ever been exactly repeated, viz. $46^{\circ} 28^{\prime} \mathrm{N}$. lat., $8^{\circ} \mathrm{oI}^{\prime} \mathrm{W}$. long. (Dana stations $\mathrm{I} 387$ on 25 June I922, and 4I 58 on I7 June I930). Choice of standard stations will not be much restricted by history but will depend much more upon the position of submarine valleys and spurs in the neighbouring continental slope.

\section{SUMMARY}

The properties of 'Mediterranean' water reaching the threshold of the Celtic Sea are outlined. This water may be recognized not only by its relatively high temperature and salinity but by an oxygen content between 65 and $69 \%$ saturated. The name 'Gulf of Gibraltar' water is preferred.

Due to admixture of nutrient-rich North Atlantic Central water, the Gulf of Gibraltar water in the neighbourhood of the Celtic Sea is fairly rich in nutrients, and the large 'anomaly of the nitrate- $\mathrm{N}$-phosphate-P ratio found in its region of origin has largely disappeared.

The extension of the Gulf of Gibraltar water into the eastern North Atlantic 
is very variable both in space and time and, at a given position, very large changes in temperature and salinity may occur in a few months.

The Thor investigations in 1906 revealed that the Gulf of Gibraltar water may be held into the right against the continental slope of the west European coast and not extend very far to seaward. Between 1000 and $2000 \mathrm{~m}$. depth south of the Celtic Sea variations in phosphate-P content of at least $0.2 \mu \mathrm{g}$.atom/l. seem to have occurred.

The properties and upper and lower limits of North Atlantic Central water in the area have been examined. Well away from the continental slope the upper limit of Central water, conforming to its $T-S$ relation, and the lower limit of winter mixing have lain between 75 and $100 \mathrm{~m}$. depth. Approaching the slope the apparent depth of vertical mixing becomes more than twice as great. This effect is attributed to cooled cascade water from the continental shelf which, by bringing about a state of labile equilibrium, assists mixing to a greater depth by wind and by processes such as capsizing of water masses peculiar to the continental slope.

Part of a survey of a section of the continental slope by H.M. surveying ship Dalrymple revealing a rugged topography is reproduced (Fig. Io).

It is possible to identify the several water masses in the vertical section worked south-west of the Celtic Sea in June I9I4 by the Norwegian research vessel Armauer Hansen (Fig. I I), viz. (i) North Atlantic Deep water below approximately $2000 \mathrm{~m}$.; (ii) between $\mathrm{I} 200$ and $2000 \mathrm{~m}$. water formed by mixing of Deep water and Gulf of Gibraltar water and conforming well to the $T-S$ relation given as equation (I); (iii) between 800 and $1200 \mathrm{~m}$. depth Gulf of Gibraltar water showing a salinity maximum and oxygen minimum, and warm; (iv) North Atlantic Central water conforming to equation (2), $700 \mathrm{~m}$. thick at Armauer Hansen station I5 (Figs. 8 and 9) and thinning out towards the shelf which it did not reach; (v) an intermediate region of mixed Central and Gibraltar water; (vi-viii) three layers of cascaded waters lying against the continental slope, the uppermost one extending from the surface down to $400 \mathrm{~m}$. depth and derived largely from the Celtic Sea and further mixed by capsizing processes, and two others at about 800 and at $1200 \mathrm{~m}$. depth of northern origin: the Porcupine Bank and the Rockall Table Mount are tentatively suggested as the sources of these; and lastly (ix) at stations Io and II, 200 miles off the continental slope, a core of highly oxygenated water (86-94\% saturated) and having temperature and salinity appropriate to the Celtic sea the preceding winter. This core is considered to be a cascade phenomenon whose understanding demands further knowledge of the topography and oceanography of the continental slope.

It is considered probable that these water masses of very different physical and biological histories will have acquired different contents of chemical micro-constituents. These may affect organisms for good or ill at sensitive stages in their life histories, e.g. development of diatom-resting spores, 
fertilization and hatching of eggs and moulting of crustaceans. When 'Atlantic' water enters the Celtic Sea and English Channel, the particular kind needs to be identified.

On I8-I9 January, I950, R.R.S. William Scoresby worked four stations over the western continental slope of the Celtic Sea along the parallel $50^{\circ} 34^{\prime} \mathrm{N}$. and on II-I2 May, R.R.S. Discovery II worked three over the southern slope in about $7^{\circ} 40^{\prime} \mathrm{W}$. (Fig. 8). At no depth were the two sections closely related.

On the northern January section vertical mixing had extended to $250 \mathrm{~m}$. and there was little horizontal difference in temperature or density. Total phosphorus and inorganic phosphate increased westward by $0.1 \mu \mathrm{g}$.-atom/1. in 30 miles. Along the southern section in May there was no relict isothermal, isopycnal layer from the winter.

The twenty-seven sets of observations made by the Irish Fisheries Service at their position ' $\mathrm{SS}$ ', $50^{\circ} 34^{\prime} \mathrm{N}$., $\mathrm{II}^{\circ} \mathrm{I} 7^{\prime}$ ' W., have been submitted to statistical examination. Mean temperatures, salinities and densities are set out in Table XV, together with standard deviations. The water there at $800-1000 \mathrm{~m}$. depth and also at similar depths in the open Atlantic at $44^{\circ} 36^{\prime}$ N., $20^{\circ} 00^{\prime} \mathrm{W}$. shows a greater standard deviation and range of temperature and density than any other strata below $150 \mathrm{~m}$. Currents there must be of the same order of magnitude as at $100 \mathrm{~m}$. depth.

The conflict south-west of Ireland between Gulf of Gibraltar water and cascaded waters from the north is described. It is suggested, but not proved, that much of the northern cascaded water has been created over the Rockall Table Mount and flows south at about 5 miles a day. At station SS there is at $800-1000 \mathrm{~m}$. depth a seasonal change in temperature with a range of about $0.5^{\circ} \mathrm{C}$.

Immediately west of the British Isles in spring and summer geopotential topographies, derived from the distribution of density, suggesting surface currents to the north and north-east need to be interpreted with especial care. A mid-water descending current in the opposite direction and of considerable magnitude is always likely. The effect upon the survival of diatoms and of animal plankton of a cyclical process involving this mid-water return current is examined.

During 1927 as a whole, water movements around $800-1000 \mathrm{~m}$. were on a scale larger than in any other year for which we have sufficient records.

At $200-400 \mathrm{~m}$. depth the average seasonal changes in temperature were only one-fitth of those at $800-1000 \mathrm{~m}$. Since 1927 the stratum of water between 200 and $400 \mathrm{~m}$. has become warmer. In January 1950 it was $0.5^{\circ} \mathrm{C}$. warmer than the mean of all observations. The relevance of these results to the widely held view that the Northern Hemisphere is warming up is discussed. 


\section{REFERENCES}

ARMStrong, F. A. J., I95I. The determination of silicate in sea water. Fourn. Mar. Biol. Assoc., Vol. 30, pp. 149-60.

AtKIns, W. R. G., I928. Seasonal variations in the phosphate and silicate content of sea water during 1926 and 1927 in relation to the phytoplankton crop. Fourn. Mar. Biol. Assoc., Vol. 15, pp. I9I-205.

Beaugé, L., 1934. Entrée ouest de la Manche. Carte 2. Haut fond du Président Théodore Tissier. (Carte préliminaire-Août 1934.) Paris: Office des Pêches Maritimes.

Bôto, R. G., I945. Contribuïçäo para os estudos de oceanografia ao longo da costa de Portugal. Fosfatos e nitratos. Trav. Stat. Biol. Maritime Lisbonne, No. 49, I02 pp.

BRENNECKE, W., I92I. Die ozeanographischen Arbeiten der deutschen antarktischen Expedition I9II-I9I2. Archiv. deutsch. Seewarte, Bd. 39, pp. I-2I6.

CONSEIL INTERNATIONAL POUR L'EXPLORATION DE LA MER. Bulletins Hydrographiques, published annually. Copenhagen. [Text references refer not to year of publication but to the year appearing as part of the title of each issue.]

Cooper, L. H. N., 1937. On the ratio of nitrogen to phosphorus in the sea. Fourn. Mar. Biol. Assoc., Vol. 22, pp. I77-82.

I938a. Redefinition of the anomaly of the nitrate-phosphate ratio. Fourn. Mar. Biol. Assoc., Vol. 23, p. 179.

— 1938b. Salt error in determinations of phosphate in sea water. Fourn. Mar. Biol. Assoc., Vol. 23, pp. I7I-8.

- $1952 a$. Processes of enrichment of surface waters with nutrients due to strong winds blowing on to a continental slope. Fourn. Mar. Biol. Assoc., Vol. 30, pp. $453-64$.

- $1952 b$. Factors affecting the distribution of silicate in the North Atlantic Ocean and the formation of North Atlantic deep water. Fourn. Mar. Biol. Assoc., Vol. 30, pp. 5II-26.

Cooper, L. H. N. \& VAux, David, I949. Cascading over the continental slope of water from the Celtic Sea. Fourn. Mar. Biol. Assoc., Vol. 28, pp. 719-50.

DANa Report No. 12, I937. Hydrographical observations made during the 'Dana' Expedition 1928-30. Copenhagen, Carlsberg Foundation. 46 pp.

Fraser, J. H., I950. Plankton investigations from Scottish research vessels. Cons. Int. Explor. Mer, Ann. Biol., Vol. 6, pp. 9I-5.

GAARDER, T., I927. The cruises of the Armauer Hansen. No. 2. Die Sauerstoffverhältnisse im östlichen Teil des nordatlantischen Ozeans. Geofys. Publ., Oslo, Vol. 4, No. 3, 72 pp.

HARVEY, H. W., I923. Hydrographic features of the water in the neighbourhood of Plymouth during the years I92I and 1922. Fourn. Mar. Biol. Assoc., Vol. I3, pp. 225-35.

- 1948. The estimation of phosphate and of total phosphorus in sea waters. Fourn. Mar. Biol. Assoc., Vol. 27, pp. 337-59.

Helland-Hansen, B., 1930. Physical oceanography and meteorology. Rep. Sci. Res. 'Michael Sars' North Atlantic Deep Sea Exped. I9Io, Vol. I, II5 pp. (Pt. I), I02 pp. (Pt. 2).

- 1949. Remarks on some variations in atmosphere and sea. Glaciers and climate, geophysical and geomorphological essays dedicated to Hans W: son Ahlmann. Geografiska Annaler, Häfte I-2, pp. 75-82.

Helland-Hansen, B. \& Nansen, F., I927. The cruises of the Armauer Hansen. No. I. The eastern North Atlantic. Geofys. Publ., Oslo, Vol. 4, No. 2, 76 pp. and $7 \mathrm{I} \mathrm{pl}$. 
Jacobsen, J. P., 1929. Contribution to the hydrography of the North Atlantic. The Danish Dana Exped. 1920-22, Vol. I, Oceanogr. Rep. No. 3, 98 pp. Copenhagen.

LAUZIER, L., I950. Température des eaux de surface exceptionellement élevée en 1949. Fisheries Res. Bd., Canada, Prog. Rep. Atlantic Coast Stations, No. 5I, p. I9.

Nansen, F., I912. Das Bodenwasser und die Abkühlung des Meeres. Int. Rev. Ges. Hydrobiol. Hydrogr., Bd. 5, pp. I-42.

NiELSEN, J. N., I9I2. Hydrography of the Mediterranean and adjacent waters. Rep. Danish Ocean. Exp. I908-I910, Vol. I, pp. 77-I91. Copenhagen.

SANDSTRÖM, J. W., I9I8. The hydrodynamics of Canadian Atlantic waters. Canadian Fisheries Expedition, I914-15, pp. 221-343. Ottawa.

Schmidt, J., I9I2. Hydrographical observations. Rep. Danish Ocean. Exp. 1908-10, Vol. I, pp. 53-75. Copenhagen.

SMED, J., I949a. Monthly anomalies of the surface temperature in the sea round Iceland during the years 1876-1939 and 1945-1947. Cons. Int. Explor. Mer, Ann. Biol., Vol. 4, pp. II-26.

- 1949b. Monthly anomalies of the surface temperature in areas of the northeastern North Atlantic during the years 1876-1939 and 1945-1948. Cons. Int. Explor. Mer, Ann. Biol., Vol. 5, pp. II-I5.

- I950. Monthly anomalies of the surface temperature in areas of the North Atlantic during the years 1876-1939 and 1945-1949. Cons. Int. Explor. Mer, Ann. Biol., Vol. 6, pp. I8-27.

Storrow, B., 1925. Fluctuations in fisheries. Trans. Nat. Hist. Soc. Northumberland, Durham and Newcastle-upon-Tyne, N.S., Vol. 6, pp. 182-200.

Sverdrup, H. U., Johnson, M. W. \& Fleming, R. H., 1942. The Oceans. 1087 pp. New York.

TAIT, J. B., I95I. Oceanic influence in and around the North Sea. Weather, Vol. 6, No. 3, pp. $85-6$.

Thomsen, H., I931. Nitrate and phosphate contents of Mediterranean water. Rep. Danish Ocean. Exp. I908-I910, Vol. 3, No. 6, I4 pp. Copenhagen.

Vallaux, C., 1936. The deep circulation in the Atlantic Ocean. Hydrogr. Rev., Monaco, Vol. I3, No. 2, pp. 32-45.

WILSON, D. P., I951. A biological difference between natural sea waters. Fourn. Mar. Biol. Assoc., Vol. 30, pp. I-20.

\section{APPENDIX}

\section{Methods USED IN THE I950 INveSTigations}

The Nansen-Pettersson insulating water-bottle was used down to $400 \mathrm{~m}$. at R.R.S. William Scoresby stations on I8-I9 January and R.R.S. Discovery II stations on II-I2 May I950, except at station WS962 (to $200 \mathrm{~m}$.) and Discovery II station 2658 (to I50 m.). Discovery pattern reversing bottles were used at greater depths. All temperatures are appropriately corrected to give temperatures in situ. All salinities were determined by the Government Chemist.

The analyses of oxygen samples collected on R.R.S. William Scoresby were completed by Dr T. J. Hart and Mr R. I. Currie on 26 January in the ship's 
laboratory whilst lying at Devonport. Analyses of inorganic phosphate were made by the present Plymouth procedure (Harvey, 1948) by Mr F. A. J. Armstrong between $2 \mathrm{I}$ and 23 January. Total phosphorus analyses were made on 24 January by him using Harvey's method.

All R.R.S. Discovery II samples were taken on to Malta whence they were sent back by sea. Unfortunately, they were delayed in transit and did not arrive at Plymouth until the end of July. The samples in glass bottles for analysis of salinity by the Government Chemist and in polythene bottles for silicate analyses by Armstrong's own method (I95I) were in good condition. Analyses of the inorganic phosphate samples, preserved though they had been, were not attempted. Since the samples for total phosphorus analysis in baited polythene bottles had evidently stood upside down for some time and the accuracy which may be read into them has proved of much importance, it becomes necessary to quote $\mathrm{Mr}$ Armstrong's detailed comments on his analyses:

The volume of each sample was measured before autoclaving. It should have been $69 \mathrm{ml}$. (67 ml. of sea water $+2 \mathrm{ml}$. reagents). In every case it was less. After autoclaving the volume was adjusted to $68 \mathrm{ml}$. by adding distilled water and the analysis completed.

Fifty of the 59 samples showed deficiencies in volume of 2-8 ml., 8 of 9-14 ml. and one (Station 2655 , I0 m.) of $25 \mathrm{ml}$. Deficient volume was assumed to be the result of evaporation or spillage and it seemed likely that both had occurred. Leakage of salt water from some bottles was evident because incrusted salt was seen around the stoppers and on the underside of the lid of the box. Loss by evaporation alone would not matter since it would be made up after autoclaving, during which evaporation occurs anyway.

If the samples were homogeneous, spillage could be allowed for in calculation. The variable salinity of the samples, which might be expected to introduce small and variable 'salt errors' into the analyses, does not matter since salt errors are compensated by the 'subsequent addition of phosphate' technique of Harvey (1948, p. 35I). Loss of sample can be allowed for by multiplying the first result found by the ratio unspilt volume/volume found, where 'unspilt volume' is the original volume of $69 \mathrm{ml}$. less that volume lost by evaporation. Since it was impracticable to find out what proportion of the losses in each sample was due to evaporation, it was assumed arbitrarily that each sample had lost $2 \mathrm{ml}$. in this way, and the unspilt volume was taken to be $67 \mathrm{ml}$.

However, the samples were not homogeneous, since they contained a $\operatorname{Th}\left(\mathrm{CO}_{3}\right)_{2}$ suspension likely to occlude or adsorb phosphorus so that another unknown error, difficult to estimate, is involved. The results have therefore been given to the nearest $0.1 \mu \mathrm{g}$.-atom $/ 1$. The true value of a result reported as, say, 0.7 is believed to lie between 0.65 and 0.75 . 